\title{
Espacios del arte y el acecho de un fin: transitividad, porosidad y desaparición
}

\section{Spaces of art and the haunting of an end: transitivity, porosity and disappearance}

\author{
Rosa María Droguett Abarca \\ Pontificia Universidad Católica de Chile \\ rdroguet@uc.cl
}

\section{Resumen}

Ante la interrogante sobre el agotamiento o fin del arte en la posmodernidad, y el creciente dinamismo y porosidad de sus espacios, se propone la idea de fenómenos "en tránsito", donde la finitud sería reflejo de una crisis, pero también, el input para un nuevo estatuto estético y museológico. El fundamento estaría en la existencia de un tipo de arte y una estética de naturaleza topológica caracterizados por el desplazamiento, tal como lo propone Nicolas Bourriaud, y el museo como catástrofe o ruina planteado por Víctor Stoichita y Jean-Louis Déotte. Estos marcos especulativos se pondrán en tensión con dos proyectos que plantean un vaivén entre lo material y lo inmaterial que es mediado por el lenguaje, así como la literal errancia de los proyectos.

Palabras clave: Museal, Desplazamiento, Porosidad, Transitividad.

\begin{abstract}
When facing the question about the exhaustion or the end of art in postmodernity, and the increasing dynamism and porosity of its spaces, we propose the idea of phenomena "in transit", where the finitude would be the reflection of a crisis, but also the input for a new aesthetic and museological statute. Its basis would be in the existence of a kind of art and a aesthetics of topological nature characterized by displacement-as proposed by Nicolas Bourriaud-and the museum as a catastrophe or ruin-as proposed by Victor Stoichita and Jean-Louis Deotte. These speculative frameworks are tested against two projects that bring forward the coming and going between the material and the immaterial mediated by language, as well as the literal roaming of projects.
\end{abstract}

Keywords: Museal, Displacement, Porosity, Transitivity. 


\section{Ad Portas}

¿Qué es lo que se agota y está hoy en crisis en el campo de la estética y la creación artística? Responder a esta pregunta nos remite al problema de la finitud: la catástrofe y el acecho del fin se pondría en escena tanto en el arte mismo, como en los espacios que lo cautelan -paradójicamente- fuera de sus límites, por medio de operaciones estético-políticas y múltiples redes que surgen o se proponen en tensión a los controles institucionales.

Es preciso partir de tres supuestos teóricos. En primer lugar: la museología crítica en tanto disciplina ${ }^{1}$, ha planteado que ella es necesaria para comprender el arte, de la misma forma que la teoría y la historia del arte (Hernández 85), por lo cual es un área válida de especulación filosófica y estética. Por esta razón, el museo es un espacio esencial "porque el arte es ante todo, aquello que es objeto de experiencia estética, y esta (la del museo) es una reconfiguración de los espacios-tiempos de una sociedad" (Rancière, Sobre Políticas Estéticas 69). Junto a esto y en segundo lugar, existe una topografía del adentro y el afuera como lo propone Rancière refiriéndose a los espacios del arte ${ }^{2}$, lo cual exige hacerse cargo de la porosidad y movilidad que se encuentran involucradas en las coyunturas y circuitos del arte.

En tercer lugar, los territorios museales actuales, en tanto ámbitos diversos que permiten la visibilización de arte en diálogo con el medio (museos nacionales, galerías, centros de arte o bienales), se constituyen en el espaciotiempo antes mencionado ${ }^{3}$. Desde los desplazamientos que suscitan, éstos se vinculan con la representación de los imaginarios que un individuo a principios del siglo XXI posee del mundo, donde espacio y tiempo se confunden e intercambian sus propiedades; se disponen por lo tanto permeables al medio (artístico, cultural y social), desbordando lo cotidiano.

Planteamos la hipótesis de que en coherencia con los proyectos artísticos contemporáneos de naturaleza nómade y flexible, los espacios de visibilización del arte tienden a proyectarse "en tránsito", con una consecuente precariedad ontológi-

1 Para Francisca Hernández (Planteamientos teóricos de la museología, 2006) la llamada Museología Crítica es una disciplina especulativa con efectos prácticos, que hace del museo y los espacios del arte como ámbitos en conflicto productivo, donde el patrimonio, la identidad y otros conceptos son puestos en discusión. Se deja atrás la idea de este espacio como dispositivo neutro, pasando a ser el resultado de discursos y dispositivos que están operando en un momento y lugar dado.

2 En "Sobre politicas estéticas" (2005), Rancière se hace cargo de la oposición entre arte in situ y arte del museo; las transacciones programáticas (ver hipótesis 2) detentan "programas que ponen en juego de una manera sistemática las contradictorias relaciones entre un dentro y un afuera" (65). El filósofo dice que uno de los rasgos comunes de las transacciones programáticas es este tipo de topografía, mirando estos ámbitos artísticos como espacios metamórficos, que incluso se abren a la mezcla de las artes (76).

3 Precisemos este concepto filosófico desde la física, con las palabras de Richard Price en el libro: Hawking S, et alt. El futuro del Espaciotiempo. Madrid: Crítica, 2007: "sucesos" son los lugares en el espaciotiempo. Un suceso es cierto lugar y cierto tiempo (puede pensarse la relación clara entre el suceso y el ser aquí y ahora de Heidegger) Evidentemente el mundo de tales sucesos - el mundo que llamamos espaciotiempo- es tetradimensional. Se necesitan tres coordenadas para especificar el "dónde" (consideremos las ideas de "alto, largo y ancho" como ejemplo más típico (cartesiano), pero no el único sistema posible) de un suceso, y una coordinada para especificar el "cuándo" (21, los paréntesis son nuestros). 
ca. Ante esto, creemos que el acecho constante del fin y un posible agotamiento sin vuelta atrás, es solo aparente ya que, tomando a Walter Benjamin, lo catastrófico está contenido en la idea de progreso; no es fin o destrucción, sino la interrupción generativa de nuevas posibilidades dentro del continuo: las posibilidades de lo transitivo. Ahora bien, si hablamos de territorios que se configuran desde los trayectos de un sujeto estético, el vaivén entre el adentro y el afuera rancieriano, se sustenta en una estética que posee como base la topología. Esta disciplina posee una función teórica fundamental por su relación con el espaciotiempo y el territorio, el cual se constituye desde los desplazamientos de quienes lo recorren ${ }^{4}$.

En relación a la precariedad ontológica de los espacios del arte, se pueden instalar los conceptos de desplazamiento, porosidad y transitividad. Esto abre el diálogo con ciertos aspectos de la estética radicante propuesta por Nicolás Bourriaud ${ }^{5}$; ya que al tender al tránsito, se entregan a la movilidad de individuos, sujetos, naciones y culturas. Desde lo anterior, estos ámbitos se disponen a la tensión y encuentro con la megalópolis, en tanto "ciudad porosa" o "trashumante", y gracias a operaciones de apertura y migración ${ }^{6}$, se facilitan colecciones, proyectos e imaginarios artísticos que se desplazan y mutan, con la radical ausencia de un propósito fijo y predeterminado (a diferencia de lo que ocurría en la modernidad). Los conceptos de movimiento, conectividad, porosidad y tránsito - en un giro que pone en escena un tiempo que se espacializa, pues se mueve, o se constituye por medio de trayectos (Radicante 89)- se instalarían para poner en jaque el fin antes enunciado, y anunciar un nuevo comienzo.

Pero ¿se puede aludir a lo museal como núcleo de los diversos espacios del arte? Es preciso disponerse a su tensión estético-política y tomar partido por su sello para imbricarlo con la trama que propone este estudio.


por su relación con el espaciotiempo y con un territorio que se constituye desde los desplazamientos de quienes lo recorren. Para conectar la topología con la propuesta del tránsito, es clave la idea de geoproceso, entendida como "transformación de capas vectoriales mediante vectores de desplazamiento". Es considerado tanto por Deleuze en Mil Mesetas, capitalismo y ezquizofrenia, en Déotte en La Ciudad Porosa, como en Bourriau en Estética Relacional $y$ Radicante.

5 Nicolas Bourriaud es escritor, crítico de arte y curador francés nacido en 1965. Dirigió junto con Jerome Sans en el Palais de Tokyo (París) entre 2002 y 2005; fue curador del Pabellón francés de la Bienal de Venecia (1990), en el Aperto de la misma bienal (1993) y en galerías y centros culturales de París, Nueva York, Friburgo y San Francisco, entre otras ciudades. Junto a Sans fue director artístico de la Bienal del Lyon (2005). Actualmente es curador en el Museo Tate Britain de Londres, donde organizó la Cuarta Trienal en 2009. Es autor de novelas y ensayos donde se destaca Estética Relacional (AH, 2006; reeditado en 2008), Postproducción (AH, 2004; reeditado en 2006 y 2009), y Radicante (AH, 2009), que han generado gran impacto e influencia en el mundo del arte y la cultura.

6 En este contexto entenderemos la migración como un movimiento intencionado de imágenes artísticas, desde el espacio y el tiempo protegido de una institución del arte, en un vagabundeo sin destino fijo, en un bamboleo constante dentro-fuera. La migración supone la supervivencia de las imágenes (más allá del tiempo de creación), como lo plantea Aby Warburg y lo estudia Georges Didi-Huberman, pero asume en toda amplitud, su carácter nómade y errático; supone también una forma-trayecto turbulenta en el espaciotiempo como plantea Bourriaud. 


\section{Toma de posición sobre lo museal}

La crisis ad portas del museo posee una relevante dimensión que es en torno a "lo museal". ¿El concepto general de lo museal nos acerca a la idea de catástrofe, y a la resistencia de la pérdida y al olvido del patrimonio como actitud social, política y estética dentro de un determinado régimen del arte? E. Jünger en su libro El Trabajador (Arbaiter) de 1932 habla de la nueva cultura ${ }^{7}$, oponiendo sistemáticamente lo museal a la figura del trabajador: el vaivén en este caso, se da entre el trabajo (faena) del proletariado y lo museal; los beneficios del último sería recibido por la burguesía, quien podría "darse el lujo" de contemplar el arte en vez de trabajar. Lo museal sería el último reducto de la seguridad burguesa, ofreciendo escapatorias para asumir decisiones políticas, sintetizando todo lo que se trata de hacer desaparecer: el individualismo burgués.

Para nosotros lo museal tiene ciertos aspectos insoslayables que rozan la propuesta de Jünger, pero otros que hacen más sentido dentro de esta trama. Entenderemos lo museal, y así los diversos ámbitos museales, como aparatos (appareil) ${ }^{8} \mathrm{de}$ cautela y exposición de carácter estético y político, que involucra decisiones políticas, sociales, culturales y geográficas (topográficas y topológicas), en una territorialidad global y nómade. Es lo museal aquello que tendería a la crisis o a un replanteamiento constante en la posmodernidad. Esto involucra políticas estéticas y regimenes de las artes, que si bien dialogan/ forman una sensibilidad común como lo entendería Rancière, exigen en la actualidad pensar un "común” polifocal, disciplinariamente diverso, planetario y complejo.

Si se valida e invita a la conformación de propuestas de visibilización del arte en flujo y devenir, estaríamos en disposición de armar una tríada de ideaspivote: apertura, porosidad y transitividad. Si ellos son conceptos articulantes, cabe preguntarse: ¿para qué se abren los espacios del arte... para inscribirse en el mercado global, o en los nuevos campos de reflexión liderado por los curadores? Si este fenómeno se comprende como resultado de una catástrofe de la vida cotidiana (lo cual se vinculará más adelante con el Proyecto Esto no es un Museo. Artefactos

7 Nos referimos a Jünger, E., Le travalleur, 1932. Trad. fr., Hervier, J. París:Burgois, 1989, Jünger erige una suerte de metafísica productivista y guerrera en contra de aquella, de la representación del arte, que él atribuye a la burguesía. Este panorama se articula en una oposición masiva: el mundo constructivista de la obra, en contra de la forma "privada de vida" de lo museal (que no es el museo en sentido estricto) (Déotte La ciudad porosa, Walter Benjamin y la arquitectura 42,43 )

8 En francés "appareil" posee un doble alcance semántico que cual implica una conexión inicial entre técnica y apariencia, o modos de aparecer, donde toda presencia, y por lo tanto toda percepción, podríamos decir, está ya "aparatizada", adornada. (La época de los aparatos, de Jean-Louis Déotte, Buenos Aires, Adriana Hidalgo, 201) Déotte dice también que se debe recurrir a los aparatos para explicitar la conexión entre las relaciones de producción y cultura, porque, por un lado, los aparatos son técnicos, y a nombre de eso su génesis es aquella de todos los objetos técnicos (Simondon), y por otro, ellos son simbólicos, como la perspectiva según Panofsky que reconfiguró el mundo de las apariencias. Déotte, Jean-Louis: La ciudad porosa, Walter Benjamin y la arquitectura, Ediciones Metales Pesados, Santiago de Chile, 2013, pág. 20. 
Móviles al acecho), ¿qué ocurriría con el arte? ¿Se hace receptivo a las existencias cotidianas en emergencia?

Sobre la apertura y la transitividad, sentaremos como idea clave la existencia de una topografía de un intra y un extra como lo propone Rancière, que gravitará en estos espacios abiertos y movibles. Haciéndose cargo de la oposición entre arte in situ y arte del museo, el filósofo habla de "programas que ponen en juego de una manera sistemática las contradictorias relaciones entre un dentro y un afuera" (Sobre políticas estéticas 65$)^{9}$. Con el desplazamiento que esto supone, dichas transacciones se vinculan con la representación de imaginarios que un individuo contemporáneo posee del mundo, donde espacio y tiempo se confunden e intercambian sus propiedades ${ }^{10}$. Es posible observar cómo se hace necesario pensar un sujeto estético que se desplaza entre un ámbito y otro, lo cual exige conversar desde la topología como disciplina en interacción constante en este estudio.

Pero ¿quién o qué está en tránsito, quien establece un bis a bis constante con su finitud? Son muchos los qué y los quienes; aparece entre otros, el problema de la identidad del individuo, del colectivo-nación y sus creaciones culturales, de las instituciones y obras de arte... todos proyectos de amplia y compleja categorización.

\section{El tránsito: claves estéticas y museológicas en la Modernidad y Posmodernidad}

El marco problemático que contiene la idea de finitud y transitividad en el arte, tiene un lugar en el espaciotiempo: la posmodernidad. Como concepto provisorio podría entenderse como continuidad del proyecto moderno según Jürgen Habermas (El discurso filosófico de la modernidad. Doce lecciones, 1989) o como un fracaso de dicho proyecto según Jean-François Lyotard (La Condition postmoderne: Rapport sur le savoir de 1979, La condición posmoderna. Informe sobre el saber). Este último vincula la posmodernidad a la incredulidad y la pérdida de la función metanarrativa (como capacidad de crear relatos globales), con la consecuente inestabilidad lingüística de los discursos creados; seguimos a Lyotard, sin negar aquellos rasgos de modernidad que se arrastrarían hasta nosotros, bajo un nuevo contexto ¿Catástrofe ad portas o un nuevo paradigma de narración y especulación, donde se pone en cuestión nuestra

9 En Sobre políticas estéticas (2005), el filósofo dice que se trata de transacciones programáticas, y uno de sus rasgos comunes es topográfico; de hecho mira los ámbitos artísticos como espacios metamórficos, que se abrirían potencialmente a la mezcla de las artes (76).

10 Esto es para Nicolás Bourriaud, un hito clave para la estética de nuestro tiempo y la base de su Estética Radicante. Para definirla el curador y teórico asevera que: "sin lugar a dudas, el mayor hecho estético de nuestro tiempo reside en el cruce de las propiedades respectivas del espacio y del tiempo, que transforma a este último en un territorio tan tangible como las habitación de un hotel en que me encuentro, o la calle ruidosa bajo mi ventana" (Radicante 89) Una de las manifestaciones artísticas más importantes de esa "espacialización del tiempo" en el arte contemporáneo; es lo que Bourriaud llama los time-specific, como respuesta al arte site-specific de los años '60.. 
capacidad para dar cuenta de aquellos "grandes periplos y grandes propósitos"? Con esta última frase, el filósofo enfatiza la incapacidad del lenguaje para comunicar las nuevas combinaciones debido a la inestabilidad de sus propiedades y mensajes ${ }^{11}$. Este campo especulativo será fundamental para entender el alcance de la problematización y puesta en valor del lenguaje que realiza el filósofo francés, en el proyecto curatorial Les Inmateriaux (1985), que presentaremos más adelante.

Es claro que en la cultura occidental nos encontramos con una nueva actitud ante las cosas, generada por una compresión espaciotemporal, que surge de la expansión de los medios de comunicación masiva; esto justamente generaría "un cambio en la relación con el problema del sentido (¿o con el problema del fin?) (...) Si se quiere, lo que es nuevo sería el no saber cómo responder al problema del sentido" (Jean-François Lyotard, Régles et Paradoxes, 69, el paréntesis es nuestro)

Se trata de una actitud que no cree tampoco en la existencia de explicaciones metafísicas, trascendentales y totalizadoras con vibraciones empiristas y materialistas ${ }^{12}$. Es una actitud tolerante ante la diferencia, en la que la estética se ha impuesto a la ética, donde, criticando a la modernidad, se basa al mismo tiempo en sus principios pero llevados a sus últimas consecuencias. Se busca convivir con lo distinto y construir una realidad con plena conciencia de que se trata de montajes, no de hechos; de juegos de lenguaje y de discursos que replantea el saber, y no del saber mismo ante un "algo" estable y universal. Nuevamente nos visita Lyotard y su cuestionamiento sobre los alcances de un lenguaje erráticamente eficiente para expresar nuevas redes semánticas, nuevos mensajes de sentido, que haga sentido (si es que aquello tiene sentido).

Desde la idea de apertura e inseguridad, es de relevancia la idea de Bourriaud sobre un posmodernismo estético, que él describe como la "instauración de un imaginario de la fluctuación y de la fluidez que remite a ese amplio movimiento de desterritorialización por el que se realiza el capitalismo" (Radicante 52). Esto no sólo reitera la idea de oscilación y transitividad, sino que nos dispondría para la especulación sobre el peso político, económico y cultural que tendría el libre mercado y su consecuencia global, lo cual se escapa de nuestro tema.

Desde aquella desterritorialización y globalidad, fijemos alguno de los ámbitos en juego. En un cambio de época - de la modernidad a la posmodernidad-el problema de la identidad es transversal. Ha sido explicada como una "identidad en movimiento, una identidad frágil", abrazando una suerte de nomadismo, donde se trata de "una identidad que ya no es, como fue el caso en la modernidad, el único fundamento

11 “Simplificando al máximo, se tiene por 'posmoderna’ a la incredulidad respecto a los metarrelatos (...) La función metanarrativa pierde sus funciones, el gran héroe, los grandes peligros, los grandes periplos y el gran propósito. Se dispersa en nubes de elementos lingüísticos, narrativos, etc., cada uno de ellos vehiculando consigo violencias pragmáticas sui generis. Cada uno de nosotros vive en la encrucijada de muchas de ellas. No formamos combinaciones lingüísticas necesariamente estables, y las propiedades de las que formamos no son necesariamente comunicables" (Lyotard La Condition postmoderne: Rapport sur le savoir 10)

12 De allí la vinculación que estableceremos más adelante, con un empirismo de base epicúrea, o más bien lucreciana. 
de la existencia individual y social" (op cit Bourriaud sobre Michel Maffesoli, Du Nomadisme, Paris 1997, México 2004, en Radicante 39).

Ante lo anterior, supongamos que la idea de nomadismo tocaría el qué y el para qué de los museos y los diversos espacios del arte -ergo su identidad- lo que permitiría dar soporte a las nuevas propuestas teóricas y prácticas de la museología. En este escenario, aquella errancia ¿tocaría por igual los distintos ámbitos expositivos? ¿En qué espacio lo transitivo se encontraría a sus anchas? Pensamos que si bien la museología actual busca poner de manifiesto aquella identidad cultural en movimiento con obras de distintas épocas, son los proyectos actuales de arte y los espacios que los difunden los que mejor reflejan esta aporía. Nos referimos a proyectos de la segunda mitad del siglo XX y siglo XXI.

Siguiendo el hilo de la identidad, surge el problema que sustenta el discurso posmoderno y le otorga su fragilidad ontológica: la tendencia a una dialéctica que por una parte, defendería las singularidades culturales y las obras que siguen rectamente sus tradiciones; y por otra parte, aquella postura que buscaría "apostar por el surgimiento de una forma de pensamiento susceptible de operar interconexiones entre culturas dispares, sin negar por ello su singularidad" (Bourriaud, Radicante 43). Esta última optaría justamente por lo transitivo enfrentándose a lo culturalmente fijo. Ante el problema anterior, la posmodernidad no respondería ni optaría por ninguno de los polos enunciados; ella hace preguntas y nos deja al borde del abismo, o más bien, imbuidos en "mil mesetas" de poder (culturales, artísticas, políticas) o campos estriados que surgen del espacio liso y regresan a él en un vaivén constante, como diría Deleuze ${ }^{13}$.

En otro flanco del problema de las identidades "en tránsito", las creaciones contemporáneas se explicarían por el nacimiento de espacios heterogéneos y multiculturales, globales y complejos. Esta es la megalópolis universal, como la nombra Bourriaud; en tanto gran espacio habitable, establece una nueva forma de totalización: aquella simbólica y empírica de ser un "marco urbano infinito" (Radicante 38). Como topología de lucha entre inmigrantes y sedentarios, lo privado y lo público, espacio que cautela la permanencia y la convergencia... la megalópolis promueve la emergencia, la divergencia y la movilidad. Esto mismo es lo que ocurre en el arte, el cual, junto a esta ciudad contemporánea, se convierte en el lugar donde se suscita el encuentro entre estos mundos diversos, opuestos o en proceso.

Para Bourriaud, los proyectos artísticos y sus imaginarios, no se entienden como una entidad estable, convergente, categorizable y por lo tanto controlable ${ }^{14}$, si

13 Deleuze y Guatarri explicitan que "el espacio liso y el espacio estriado, "el espacio nómada y el espacio sedentario, - (...), no son de la misma naturaleza.(...) Debemos recordar que los dos espacios sólo existen de hecho gracias a las combinaciones entre ambos: el espacio liso no cesa de ser traducido, transvasado a un espacio estriado; y el espacio estriado es constantemente restituido, devuelto a un espacio liso" (Mil Mesetas, capitalismo y esquizofrenia 483-484)

14 Para nosotros esto es señal del advenimiento de un nuevo paradigma epistemológico, que toca la estética y en este marco, también a la museología; nos dice E. Morin que:"legítimamente, le pedimos al pensamiento que disipe 
no como trayecto (forma-trayecto), logrando articulaciones complejas y en cadena ${ }^{15}$. En la composición de las obras, se consideran figuras que nacen del desplazamiento espacial (errancia, trayectos, expediciones). Es así como se reitera una vez más, el lugar que le damos a la topología, la cual para el teórico y curador francés "remite así al movimiento, al dinamismo de las formas, y designa a la realidad como un conglomerado de superficies y territorios transitorios, potencialmente desplazables" (Radicante 89)

Obras fluidas que desaparecen y transitan, espacios del arte que entran en crisis y se constituyen en vehículos del individuo estético global e identitariamente errante. Obras y espacios del arte como domicilio de múltiples desplazamientos en un medio cada vez más complejo, nos dispone ante un nuevo estatuto; si bien sería el fin de lo que la modernidad ha entendido acerca de ellos, la estabilidad conceptual no es su principal característica. No lo es, no la busca, no le acomoda.

Si el arte mismo manifiesta el estado nómade de las culturas mundiales y una identidad cultural fluida y en crisis, entonces, a escuchas de lo contemporáneo, los espacios del arte deberían extremar su apertura y movilidad, aunque eso los haga deslizarse del espacio liso al estriado; desde la claridad de su rol y funciones hasta el cuestionamiento sobre la necesidad de su existencia. Los ámbitos aludidos ¿están consientes que no sólo deben promover una exhibición que sea el reflejo de una sociedad en constante cambio sino ir aún más allá? ¿La crisis estribaría en aquella imposibilidad de la cultura como lo plantea Hannah Arendt? ${ }^{16}$

A propósito de un museo en crisis de identidad, Déotte dice que salimos de la historia de las colecciones artísticas propios de la modernidad para ingresar a una suerte de colección global, abierta y múltiple, que reinterpretaría las tradiciones y las culturas, tras una operación (de naturaleza curatorial y política) de tipo cosmética ${ }^{17}$. En ella se pondría fin a la existencia de un objetivo o destino cultural singular,

las brumas y las oscuridades, que ponga orden y claridad en lo real, que revele la leyes que lo gobiernan (...) El conocimiento científico fue concebido durante mucho tiempo, y aún lo es a menudo, como teniendo por misión disipar la aparente complejidad de los fenómenos, a fin de revelar el orden simple al que obedecen" (Introducción al pensamiento complejo de Edgar Morin ,Editorial Gedisa, España, 2001, pag. 21)

15 En Radicante (2009), Nicolás Bourriaud plantea que la forma-trayecto abarca la unidad de un recorrido: "a través de un principio de composición basado en líneas trazadas en el tiempo y el espacio, la obra se desarrolla (tal como el inconsciente lacaniano) como una cadena de elementos articulados entre sí - y no en el orden de una geometría estática que le daría una unidad. Tal concepción espontánea del espacio-tiempo (...) nace en un imaginario nómada que concibe las formas en movimiento y en relación con otras (136).

16 Hannah Arendt en La Crisis de la Cultura (1968), advierte que la cultura se ve amenazada, cuando los objetos que ella ha producido y produce, son estudiados como "meras funciones del proceso vital de la sociedad, como si se encontrara ahí sólo para satisfacer alguna necesidad" (266-267).

17 Una suerte de operación de homologación, maquillaje cultural y estético, desde ciertos hilos de poder y con fines muchas veces al servicio de la "industria cultural" como diría Adorno y Horkheimer. Esto último se refiere a la capacidad de la economía capitalista, una vez desarrollados ciertos medios técnicos, para producir bienes culturales en forma masiva ("La industria cultural. Iluminismo como mistificación de masas", escrito por ambos entre 1944 y 1947, y publicado en el libro "Dialéctica de la ilustración. Fragmentos filosóficos" o "Dialéctica del Iluminismo", en otra traducción). Déotte llama "cosmética", a la estructura del "aparecer" de todo aparato (lo explicaremos más adelante); es el suplemento con el que venimos de fábrica ¿Qué es un aparato estético? Benjamin, Lyotard, Rancière (Metales pesados, 2012). 
poniendo en evidencia un cara a cara permanente con al agotamiento. Se trata de una época donde, gracias al fin de la tradición oral, de los territorios, la industrialización y la mundialización, irrumpe la "cosmética general" como "la afirmación de una comunicación general que pone entre paréntesis la singularidad de cada época y de cada mundo. Es el fin de la finitud de cada destino" (Catástrofe y Olvido 136, el énfasis es nuestro).

Por lo tanto salir de la historia de las colecciones en pos de la llamada mundialización, marcaría un tiempo de microredes, enjambres de colecciones mayores con infinitas lógicas de organización y agrupación. Ya no es una colección y su afán de completitud, sino colecciones flotantes, que se arman y desarman, mutan y truecan en otras series de diversos mundos y épocas; archivos vivos como Esto no es un museo (proyecto que veremos más adelante), que se forma desde la inestabilidad de las obras. Transitividad y movilidad absoluta de tradiciones, proyectos y sus territorios; "colecciones" de esta naturaleza se toman el mundo de los espacios del "arte".

\section{Viajeros "en tránsito", museo-ruina y una nueva museología}

La modernidad es lo transitorio, lo fugitivo, lo contingente, la mitad del arte, cuya otra mitad es lo eterno y lo inmutable.

Charles Baudelaire, El pintor de la vida moderna

¿Arte moribundo o arte sin fin sobre el fin? ¿Arte en redes y desplazamientos topológicos para creadores y sujetos estéticos idem? ¿Cómo debiera ser proyectado, mostrado y cautelado un arte de esta naturaleza? Se hace necesario replantear la museología de nuevos marcos reflexivos para sustentar la existencia de espacios del arte para proyectos inmateriales o nómades.

La Modernidad suponía un hombre-viajero que hacía territorio e instauraba distancias, a partir de sus búsquedas y errancia. Los exploradores modernos para Arendt no fueron devueltos al mundo si no a sí mismos; surge así el mundo del individuo, un mundo a su vez fundado gracias a su propio tránsito, bajo la misión de allanar y ampliar la Tierra (La Condición Moderna, 2011). Es así como el viaje inaugura la distancia de la misma manera que la emprende, transformando la tierra en un trazado cartográfico de rutas y mapas. Este planeta ya no termina donde el hombre ha fijado su hogar, pues se extiende y las distancias se acortan en el momento en que se establecen. Es por ello que proponemos hablar de pasajeros en tránsito, tránsitos infinitos. Estos son los mismos pasajeros que crean, experimentan, seleccionan, estudian y visibilizan el arte. 
La desconfianza y el agotamiento propios de la modernidad, tendría al sujeto como protagonista; en esta crisis se observa un extrañamiento constitutivo del sujeto moderno respecto de su propia condición. Frente a esto planteamos la pregunta:

¿Qué relación se puede establecer entre un sujeto que se arrastra desde la crisis moderna hasta su condición errática en la posmodernidad y el fin (constructivo y nutricio) que acecha a los espacios del arte? Hay que volver a instalar el problema del museo como ruina o la ruina del museo y la experiencia de este sujeto.

A partir de la reflexión sobre el museo moderno, es importante hacer notar la puesta en crisis manifestada por los teóricos contemporáneos de la museología. Por ejemplo, para Francisca Hernández (Planteamientos Teóricos de la Museología, 2006), las funciones del museo tradicional (moderno) han sido las de coleccionar, documentar, investigar, conservar y difundir el patrimonio natural y cultural, donde los objetos han tenido un fin en sí mismos. La teórica española asevera que bajo estas premisas el museo entra en crisis, reclamando un cambio. Por su parte, este espacio del arte precario y cuestionado representa, en su rebelde pervivencia, una modernidad diferida -como diría Déotte- ergo desplazada y decadente; su consecuencia es la decepción melancólica de parte de sus visitantes.-El museo "siempre se ocupó de las ruinas invirtiendo románticamente -como un guante- toda sistematización del caos en caos del sistema. El Museo es, a la vez, la continuación de los desafíos de la Modernidad, así como su impedimento (su extenuación) y su traspaso del límite" (Déotte Catástrofe y Olvido 132). ¿Museo en ruina o museo como ruina?

¿El museo captura y paradójicamente impide-extermina los ideales modernos? Esta institución no sólo encarnan dichos ideales, en tanto modernidad diferida, si no que, en sus versiones contemporáneas, construye proyectos y discursos sobre estos escombros. Es así como él mismo se convierte en el lugar del fin de lo moderno y con él, es sitio de la puesta en duda de los relatos universales del arte y demás intentos totalizadores ¿Es esta coyuntura la que da origen a un nuevo estatuto museológico?

En este contexto la llamada Nueva Museología se habría levantado como la ciencia que tiene por objeto desarrollar la vocación social del museo, potenciando su dimensión interdisciplinar y sus formas de expresión y comunicación, como lo afirmó F. Hernández $(2006)^{18}$. Este ámbito se haría cada vez más receptivo a un mundo inestable y movedizo, poniéndose en relación y tensión con un individuo globalizado y en exilio permanente. Esta propuesta ha avanzado en medio de los escombros de museos y espacios canónicos del arte, obligándonos a tomar una posición ante las mutaciones y sus deslindes, que bambolean entre la modernidad y la posmodernidad.

18 La Nueva Museología nace como un movimiento de profesionales con una visión alternativa a las labores museológicas que se venían realizando en los museos hasta mediados del siglo XX. Este movimiento tendrá su referente y punto de partida en la Mesa Redonda celebrada en 1972 en Santiago de Chile, organizada por la UNESCO y con el título "el papel de los museos en América Latina". Como movimiento institucionalizado y adherido al ICOM, no podemos hablar de él hasta la Declaración de Québec de 1984, y la posterior fundación del Movimiento Internacional para la Nueva Museología (MINOM) en Portugal en 1985. 


\title{
Carpeta de pruebas: proyectos museológicos y sus pistas especulativas
}

\author{
"[...] es preciso dejar claro que no nos toca a nosotros 'proveer \\ realidad' sino inventar ilusiones de lo que es concebible y no \\ presentable. [...] Los siglos XIX y XX nos han dejado una gran \\ dosis de terror.Hemos pagado muy cara la nostalgia del todo \\ y el uno, por la reconciliación del objeto y lo sensible, por una \\ experiencia transparente y comunicable. [...]La respuesta es: \\ guerra a la totalidad. Atestigüemos lo impresentable, activemos lo \\ différands, y salvemos el honor del hombre" \\ Jean-François Lyotard, La posmodernidad \\ (explicada a los niños) $)^{19}$
}

Para poner a prueba la hipótesis, consideraremos dos casos claves; estos transforman radicalmente la idea original de expositio, y deciden innovar los modos vigentes de exhibición del arte moderno hasta los años '80, extremando la labilidad. Se trata por una parte de Les Inmateriaux curada por J. F. Lyotard en 1985, en el cual se problematiza desde los alcances del lenguaje, la idea de matriz-materia, y pone en escena su reflexión sobre el vaivén entre el estatuto de la materia y el de la inmaterialidad. Por otra parte, se aludirá también a Esto no es un museo. Artefactos móviles al acecho, curada por Marti Peran (2010-2014) donde los espacios del arte se ponen literalmente en marcha, entendido como "catálogo y archivo en proceso" con más de 70 proyectos nómades en España, Estados Unidos, México, Santiago de Chile y Canadá. En el caso de los dos proyectos, será fundamental el soporte real y el rendimiento especulativo que permite la idea de "ciudad porosa" que levanta Déotte ${ }^{20}$. Nosotros remarcamos el protagonismo de un espectador-caminante, que participa, recrea y replantea las obras, como voz y discurso colectivo que se registra en un continuo (Les Inmateriaux) o como un artista, vernáculo, doméstico y espontáneo que participa activamente desde su devenir cotidiano (Esto no es un museo), haciéndolo estallar.

Estos paradójicos espaciotiempos del arte actual (o mejor, del arte aprehendido estéticamente en la actualidad), se resisten al encapsulamiento y a la vigilancia esquizomorfa

19 La posmodernidad (explicada a los niños, 26) Aquí se cita la traducción del inglés de Stella Mastrangelo, en Keith Jenkins, ¿Por qué la historia? Ética y posmodernidad, p. 123 ISSN 1688-7247 (1994) Revista uruguaya de psicoanálisis (En línea) (79-80)

20 Esto será recogido en la consideración a los problemas de: topología y ciudad; museos y cuidad porosa; coleccionista de arte y flâneur; experiencia estética de transitar la ciudad (flâneur / Libro de Los Pasajes); cuerpo (procesos fisiológicos) y la arquitectura del adentro, desde Jean-Louis Déotte y su libro "La ciudad porosa. Walter Benjamin y la arquitectura", Ediciones Metales Pesados. L'Hartmann, 2012. 
de un coto que lo separa del mundo y la contingencia. Es por eso que en el escenario nacional e internacional, se constata la existencia de nuevas prácticas que involucran alternativas heterogéneas de narración y exhibición de obras de arte (hace sentido la idea de "ex -posición" como diría Stoichita, en tanto "fuera de lugar" ${ }^{21}$ ). Se demuestra un afán de relacionalidad, un vaivén topográfico y el dinamismo topológico que reformula la idea tradicional de los dispositivos de visibilidad, estables y seguros: lo museal se pone en marcha. La museología somete a los espacios de visibilidad a un constante dentro-fuera de sus fronteras: se trasponen por ejemplo los límites de la presencia material (Les Inmateriaux de Lyotard), o de su permanencia y cautela en un espaciotiempo fijo (Esto no es un museo. Artefactos móviles al acecho de Martí Peran).

Entonces ¿en qué se convierten los espacios del arte cuando la movilidad y la permeabilidad pasan a ser las característica de nuestra época posmoderna? ¿Un museo poroso y espacios del arte en tránsito, desde y para naciones estéticamente vagabundas, y "pasajeros"-ciudadanos estéticamente errantes?

Retomando el fantasma del acecho de un fin, nos preguntamos si el museo y los distintos espacios del arte, resisten la ruina y el olvido o lo ponen de manifiesto. Siguiendo a Déotte, quien alude a Blanchot ${ }^{22}$, creemos que el museo problematiza la ruina ya que es un modo de aparecer de lo ausente, o un nuevo aparecer de lo presente (que a veces tampoco "está allí”). La estética del museo no es pura aniquilación, sino reposición en conflicto constante de lo desaparecido o por desaparecer, ya sea esto lugar, espacio, objeto, materia, gesto o lenguaje $\mathrm{e}^{23}$.

21 Nos referimos a: Stoichita, Víctor: "el museo y la ruina, el museo como ruina", en Cómo saborear un cuadro, Cátedra, Madrid, 2009. Stoichita alude a Hubert Robert quien expone en 1796 en el Salón parisino dos cuadros en diálogo: Grande Galerie du Louvre en ruines y Proyect pour éclaire la Gallérie (sic) du Musée para la voute et pour la diviser sans ôter la vue de la prolongation du local. Pero el artista realiza una serie de más de treinta imágenes sobre este tema aludiendo al valor simbólico de la Gran Galería, en torno a "la relación entre "exposición" y puesta en historia de las obras de arte" (265). La sincronía del Salón y la diacronía de la Gran Galería formaban un todo para Stoichita, y ese todo unitario, ya entraba en crisis en 1796.

22 Maurice Blanchot (1907 - 2003) fue un escritor, crítico literario e intelectual francés. Estudió filosofía en la Universidad de Estrasburgo. Fue amigo de Bataille, y más tarde de Derrida (quien le dedicó un gran libro y varios textos famosos). Han escrito, además, sobre él, Jean-Paul Sartre y Roland Barthes.

23 "Desviando en nuestro provecho una fórmula de Virilio: la estética del Museo es una estética de la desaparición. De la borradura. Justamente: porque hace aparecer" (Déotte, Catástrofe y Olvido 36) 


\section{a) El caso de Les Inmateriaux (1985)}

"Pourquoi "Inmatériaux»? La recherche est le développement dans la techno-science, les technique est les arts, et aussi la politique, s'accompagnent du sentiment que la réalité, quelle qu’elle soit, est plus impalpable, qu'elle n'est jamais immédiatement maitrisable, -bref du sentiment de la complexité des choses"

Dossier de catálogo de "Les Inmatériaux", Centre Georges Pompidou, Centre de Création Industrielle.

Grande Galérie du 5e/ 28 Mars - 15 Juillet 1985

Este es un proyecto que consecuentemente con la propuesta de su curador, JeanFrançois Lyotard, se nos escurre de las manos, y, a 27 años de su puesta en valor, se convierte en un vagabundo que viaja, se esconde y se invisibiliza: no se puede acceder fácilmente a un catálogo de un tiraje muy reducido; no podemos acceder a las obras sino por ciertos registros de un dossier en pdf, y un sitio informal en alemán con alguna presencia de imágenes. Cuando por fin tenemos un catálogo usado en la mano, Epreuves d'fécriture, accedemos a un recorrido de voces y discursos inmateriales, de obras inmateriales, a través de descripciones y tramas reflexivas cuya mediación es un lenguaje técnico (y gráfico) altamente codificado, y sin ninguna presencia de imágenes. Consecuencia: Este es un proyecto al cual la ruina y la desaparición es acecho, tema y validación. Presentamos las ganancias de un proyecto que, errático, habla de lo inmaterial y el valor del lenguaje que lo devela-oculta.

Thierry Chaput, del Centro de Creación Industrial dependiente del Centro Georges Pompidou, deseaba organizar una exposición que pusiera en evidencia las influencias de tecnologías de aquel entonces sobre los paradigmas estéticos: hablamos de la expansión vertiginosa en el uso de los computadores, la aparición de las imágenes digitales, difusión de los estudios médicos en genética, transformación de los modos de vida fruto de la instalación de una capitalismo globalizado, nuevos descubrimientos en astrofísica, entre otros. Empieza a proyectarse una exposición titulada "Nouveaux matériaux de création" (Nuevos materiales de creación), y surge la idea de invitar como encargado del proyecto a Jean-François Lyotard.

Entre el 28 de marzo y el 15 de Julio de 1985, en el Centro Nacional de Arte y de Cultura Georges Pompidou de París, tuvo lugar esta muestra de arte moderno que marcaría un hito en lo que respecta a los modos de tensionar el estatuto del arte y sus modos de visibilización. $\mathrm{O}$ mejor aún, los modos de relación activa y viva entre los proyectos artísticos y el espectador, poniendo en evidencia las relaciones entre arte, 
tecnología e información. Se trata de "Les Inmateriaux" curado por Lyotard, quien en 1979 había desatado una gran polémica al publicar La condition postmoderne. Rapport sur le savoir, obra realizada por encargo del gobierno canadiense, en tanto informe sobre la condición del saber en las sociedades desarrolladas. Esta muestra "pone en escena" esta publicación, y sobre todo, la pérdida de credibilidad de los grandes relatos de legitimación del saber, el desgaste de discursos como el marxismo, la abundancia consumista en todo orden, el cansancio ante la utopía del progreso y la apertura reflexiva y experiencial a "lo posmoderno".

Si la catástrofe es el resalto de la continuidad, esta muestra pone en catástrofe a los estatutos museológicos y artísticos existentes hasta ese momento. Pero esta catástrofe no lleva al fin, sino a un nuevo comienzo de naturaleza errática, lábil, en aparición y desaparición constante... Lo que llamaremos un arte entre comillas.

A través de un dossier de breve circulación (CNAC Georges Pompidou, Services des Archives, 1985), accedemos a las líneas teóricas fundamentales de la muestra y dos argumentos:

El primer argumento, la posmodernidad, enuncia la idea que sustentará la propuesta curatorial, instalando la duda ante un proyecto moderno, que pretendía la emancipación de la ignorancia y los avances técnicos. Asertivamente enuncia que en el siglo XX las respuestas por la identidad o la estabilidad surgen de la incertidumbre: ésta sería justamente la esencia de lo posmoderno ${ }^{24}$.

El filósofo francés problematiza el papel del sujeto en la comprensión y apreciación-vivencia de las obras de arte, más allá de las categorías o campos de conocimientos que pudieran explicarlas. Esto no sólo nos dispone una vez más ante el problema del fin del arte como construcción autónoma, sino también nos acerca a la finitud como tema, o al asunto de la crisis de la estética misma, como lugar en el sujeto posmoderno.

El segundo argumento está referido a la inmaterialidad, y desde el marco problemático de la tecnociencia, la técnica y las artes, pone en evidencia paradójicamente al cuerpo en la experiencia (hablo de paradoja, pues el cuerpo es materia y debe enfrentar la inmaterialidad desde otras vías). Este cuerpo se ve enfrentado a una realidad no palpable, que demuestra la complejidad de las cosas. Pero ¿de qué está hecha la realidad? Dice Lyotard que logramos analizar y reconstituir la "buena y bella materia", a través de fórmulas complejas; la realidad está hecha de elementos indistinguibles, organizados por las leyes de estructuras matrices, que involucran

24 “Argument 1: la postmodernité: (...) Le projet moderne d’émanciper l'humanité de l'ignorance, de la sujétion, de la misère en développant et répandant les connaissances, les techniques les arts et les libertés, est-il encore d'factualité en cette fin du XX siècle? On peut en douter (...) Les avant-gardes artistiques sont restées inconnues ou incomprises du public. Le Mouvement modern en architecture s' est soldé par l' urbanisme des nouvelles métropoles (...) Il est clair cependant que le pouvoir de l'home, depuis son corps jusqu' 'e aux galaxies, ne cesse de s' accroitre Mais á quelle fin? (..) L'incertitude engendre, en réaction, un désir de sécurité, de stabilité, d' identité. Ce désir prend mille formes; il se déguise même sous le nom de postmodernité! 
escalas espaciotemporales no humanas. En esto, las realidades son mensajes, algunos fáciles de interpretar y otros indescifrables ${ }^{25}$.

Este argumento nos dispone a la crisis de una materialidad, y así de unos materiales asibles y comprobables físicamente; y lejos de la catástrofe de la materia, abre la categoría de la inmaterialidad de la mano de una nueva sensibilidad, capaz de aprehender lo complejo y lo indescifrable en los mensajes, en ese nuevo estatuto de realidades (ya no de LA realidad).

Se enuncia luego la manifestación de la posmodernidad y la inmaterialidad a través de una "nueva sensibilidad". Se habla de un evento en que está involucrado, una vez más, el cuerpo del espectador, cuyos ojos y oídos experimentarán diversos efectos de naturaleza artística (estética). Busca el placer de experimentar la sensación de situarse en el término de la modernidad, abriéndose con curiosidad a los albores de la posmodernidad. Se enuncia el advenimiento de una "no-exposición", y resistiéndose a la tradición expositiva instalada desde el siglo XVIII, enuncia la búsqueda de "un sistema más fluido e inmaterial en la organización del espacio"26. En esta gráfica de la exposición se nos aparece un ámbito altamente poroso que favorece una circulación no esquemática, sino abierta al vagabundeo y a todos los medios de inmersión experiencial que la muestra dispone ${ }^{27}$.

El punto en común de lo que se muestra y experimenta es una progresión general, que va literalmente desde el cuerpo al lenguaje, esto es, desde experiencias que involucran la materialidad del cuerpo hasta la inmaterialidad del lenguaje. Se enuncia una "puesta en tiempo/puesta en escena”, que enfatiza una dimensión para Lyotard preponderante en la posmodernidad: el tiempo. Su conquista es uno de los nuevos desafíos ${ }^{28}$. Nos encontramos entonces, con la vivencia de un trayecto que se viaja con

25 "Argument 2: l'immatérialité : Pourquoi «Inmatériaux » ? La recherche et le développement dans la techno-science, les techniques et les arts, et aussi la politique, s'accompagnement du sentiment que la réalité, quelle qu'elle soit, est plus impalpable, qu'elle n’est jamais maitrisable - bref du sentiment de la complexité des choses (...) D’abord les réalités sont pour nous des messages (...) A la fin la bonne et belle matière elle-même nous parvient analysée et reconstituée en formules complexes. La réalité est faite déléments indiscernables organisés par des lois de structure (matrices) à des échelles d'espace et de temps inhumaines (...) La manifestation. Une nouvelle sensibilité. Il ne s'agit pas d’expliquer de rendre sensible au public cette problématique par les formes sous lesquelles elle apparait dans les arts, les littératures (...) et les modes de vie»

26 JF Lyotard, Entrevista de Bernard Blistène Del periódico Flash Art, \#121, Marzo 1985. Blistène es profesor, director y conservador de museos franceses; desde el 2013 es el director del Museo Nacional de Arte Moderno de Francia, MNAM.

27 "Así que en vez de murallas tendremos un sistema de correas que estarán conectadas desde el techo hasta el suelo y la forma en la que ellas estarán iluminadas nos permitirá variar las distancias que el ojo puede cubrir y modular las indicaciones que deberían ser seguidas, pero sin ser prescriptivas, ya que muchos de los lugares que estaremos construyendo se encontrarán en la forma de intersecciones que permiten luego ir en cualquier tipo de dirección. (...) Cada uno de los visitantes tendrá una especie de Walkman y a pesar de que no sintonizarán distintas estaciones, ellos se moverán desde un programa a otro a medida que avanzan en la exhibición. Los programas cubrirán múltiples sitios a la vez. Esta es una forma de permitirme crear un soundtrack de comentarios que ni siquiera serán comentarios reales en absoluto y el elemento textual incluido en la visita a la muestra será una presencia considerablemente más poderosa que lo usual. También habrá música y otros efectos de sonido" (ibid)

28 "La manifestation. Une nouvelle sensibilité. Il ne s’agit pas d’expliquer de rendre sensible au public cette problématique par les formes sous lesquelles elle apparait dans les arts, les littératures (...) et les modes de vie. Cette manifestation ne fait qu'en présenter aux yeux oreilles certains des effets, comme le ferait une ouvre d’art.(..) Elle voudrait faire 


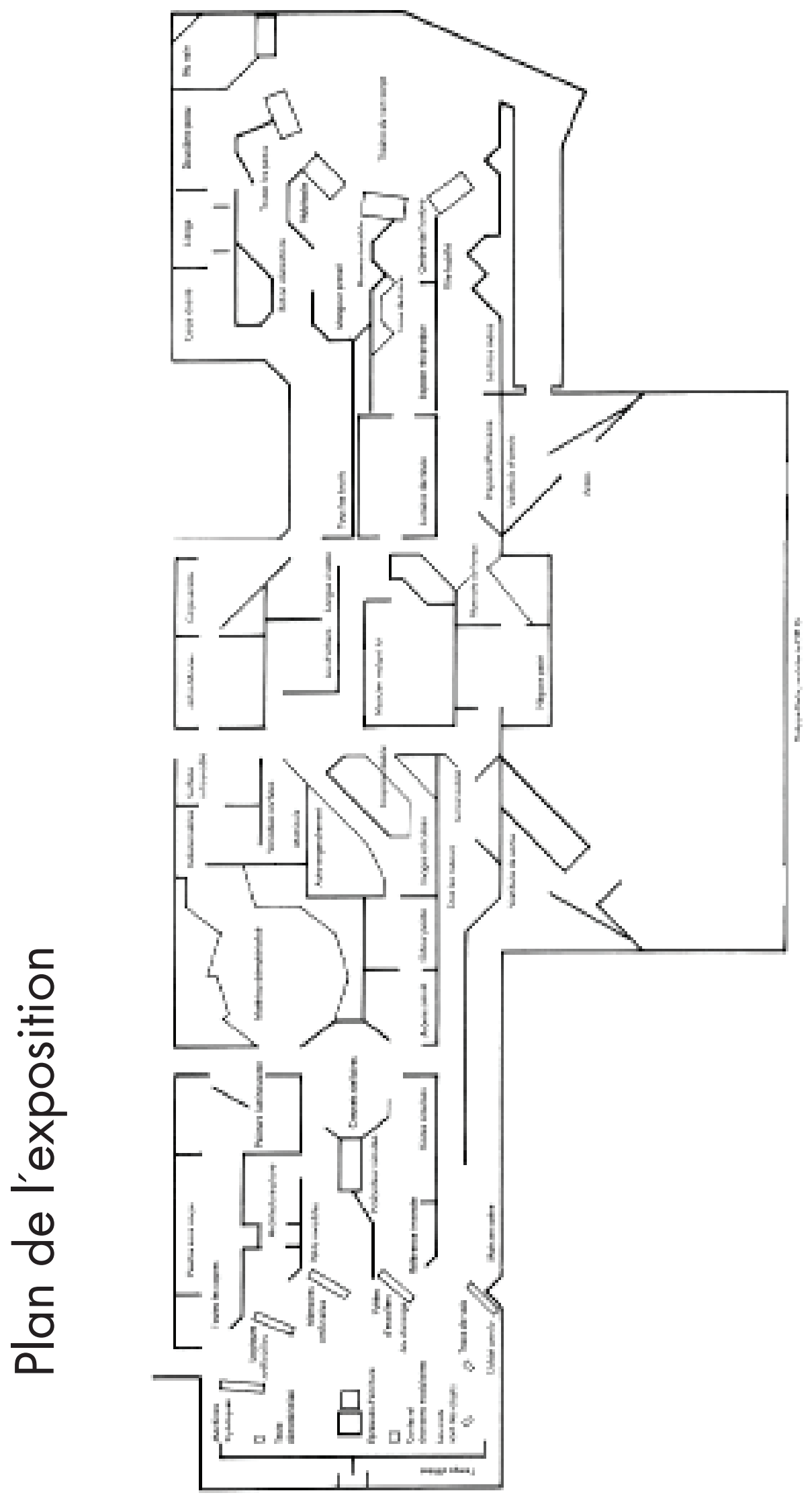


un cuerpo (¿topología?); un desplazamiento concreto y teórico de un cuerpo que en un continuo, toma conciencia estética del advenimiento del lenguaje inmaterial y que se hace parte de la construcción colectiva de nuevos discursos.

Entonces, Lyotard propone retomar la cuestión de los "nuevos materiales" (idea inicial de Chaput) pero radicalizando los modos de visibilización de las artes conocidos hasta ese momento. A partir de los cambios tecnológicos que entonces entran en escena, refiere como decíamos, a un nuevo estatuto de la materia (en el arte): el de la “inmaterialidad”. Esto alude para el pensador, a la interacción del ser humano con el universo y consigo mismo (en tanto organización de materia cósmica), lo cual supone una interacción a su vez con una red de conocimientos, sin distinción o adscripción sólo a las ciencias humanas ${ }^{29}$. En la entrevista que Bernard Blistène (BB) le hace a Lyotard (JFL) (ver pie de página 25), se habla de las redes de imbricación que están detrás de la armazón teórica de la muestra. Esto tiene una concreción en la museología de la no-exposición: "la interacción general", que pretende poner de manifiesto un aspecto de lo posmoderno como campo vasto e indeterminado; es justamente la tensión con el fin-inicio que nos convoca: “(...) lo posmoderno (...) (sería) una especie de duelo o recuerdo respecto de la Era Moderna, una suerte de desorden”. Es esta exhibición la que pretendió reactivar el caos en lugar de apaciguarlo, "puesto que ya no tiene importancia el apaciguarlo" (ibid pie de página 25)

Lyotard trabaja a partir de cinco ejes conceptuales, que pueden plantearse como preguntas, que son las que abrirían el cuestionamiento humano frente a esta "nueva era": ¿De dónde vienen los mensajes que captamos (¿cuál es su "maternidad”)?, ¿A qué se refieren dichos mensajes (¿cuál es su "matriz")?, ¿Según qué códigos dichos mensajes son descifrables (¿cuál es su "materia”)?, ¿Sobre qué "soporte" se inscriben (¿cuál es su "material”)?, ¿Cómo se transmiten dichos mensajes a los destinatarios (¿cuál es la "materialidad” de esta dinámica)? Las cinco preguntas conforman secuencias y desplazamientos, que se arman y desarman aleatoriamente desde la experiencia del espectador que las activa y el creador que las recrea, las observa...y nosotros, 27 años después, lo reconstruimos en un recorrido especulativo ${ }^{30}$.

Podríamos decir que los cinco conceptos organizadores de la exposición son: Maternidad-Matriz-Materia-Material-Materialidad. La cuestión de la "maternidad"

éprouve le sentiment l'achèvement d'une période et la curiosité inquiète qui nait à l'aube de la postmodernité. Les parcours ont en commun une progression générale, qui va du corps ou langage. Une non exposition. Le sujet même de la manifestation remet en cause la présentation traditionnelle des expositions, héritières des salon du XVIII siècle et des galeries. (...) Les parcours ont en commun une progression générale, qui va du corps au langage. Mise en temps/mise en scène. Une des dimensions prépondérantes de la postmodernité est le temps ; sa conquête en est un des nouveaux défis "

29 Nuevamente esto nos remite necesariamente a Edgar Morin y el paradigma de la complejidad que propende entre otras cosas a la unión de conocimiento disciplinares y al principio de la incertidumbre como camino deseable y válido para el hombre del siglo XXI.

30 "JFL: (...) Y hemos vuelto aquellas cinco preguntas en cinco secuencias individuales que se extenderán desde el Sur al Norte de la larga galería del Centro Georges Pompidou. Esto significa que el espectador que sigue una de esas entrevistas sobre una línea recta continuará en una sucesión llamada "Matériaux", "Matrice", "Matière", "Materiel" or "Maternité" (Ibid pie de página 25) 
refiere a un cuestionamiento en torno al origen, radicalmente negado en la posmodernidad. Sin origen, sin destino, sin "materia" física estable -es la ley del código y del algoritmo las que predominan hoy en día-, podemos, según Lyotard, disfrutar de la "libertad de los huérfanos" 31.

En esta sociedad de los medios y la información, se erige un pivote teórico que problematizaría las cinco preguntas antes enunciadas: la teoría de la comunicación; el mismo JF Lyotard habla sobre la idea de "un mensaje que finalmente entrega información sobre algo"32.

Sobre la legitimación de ese „monstruoso neologismo” lyotardano: los inmateriales, el filósofo pone en duda la existencia de materiales y de la materia, e insta a deconstruir la estructura material de objetos (y obras). Se cae en una ruina provechosa: es la crisis de la aurática materialidad de la obra en la modernidad. Pero si la obra posmoderna ya no supone material-materia y puede constituirse bajo otro estatuto ontológico ¿cómo podría existir un museo o espacio del arte para inmaterialidades? ¿Qué es lo que cae en ruina, y en el otro polo, qué es lo que se podría preservar en estos espacios? ¿Se preserva la energía, la idea, el mensaje? Estas interrogantes se encontrarían a la base del trabajo filosófico-curatorial de Lyotard; más, el gran valor fundacional de Les Inmateriaux es no pretender dar respuestas, sino instalar la incertidumbre en pro de experiencias no definitorias, experimentales, transitivas. Tentativamente dice que todo el progreso científico y artístico, se ha conectado a un conocimiento cada vez más cercano a lo que generalmente llamamos objetos (materiales) o del pensamiento humano. Pero, estructuralmente esto no sería más que energía ${ }^{33}$.

Bajo la validación de lo inmaterial, esta muestra permitió que por primera vez el público interactuara con computadores, máquinas de producción de imágenes digitales, que percibiera su trayectoria registrada por sensores, y que al final de la exposición se estableciera un diagrama preciso de las "actitudes" del visitante durante la Exposición. Esto último puso de manifiesto cómo las nuevas tecnologías invisibles ejercen el control de la población, uno de los ejes relevantes en la curatoría. El filósofo expone que su criterio de selección ha sido la exhibición de cosas que causaran

31 "BB: Has construido tu exhibición alrededor de la raíz de la palabra que hace de título: "Mat". ¿Por qué has hecho eso? (Del lat. Materǐa -ae cuya raiz, acotación nuestra) JFL: Comenzamos a pensar sobre "Mat", la cual es una Antigua raíz Indo-Europea. Pero ahora, por supuesto, sabemos que es todo una mentira (...) En cualquier caso, de cualquier forma, podemos decir que se encuentra en toda cantidad de idiomas (...) Esta raíz es una indicación de "Tomar mesura por la mano" y muy rápidamente toma el significado de "construir" o "modelar". Y es desde ahí que comprendemos las palabras como "materiales", "materia”, "maternidad”, "matrix"( Ibid pie de página 25)

32 “JFL: (...) Comenzamos por": la maternidad del mensaje, "se trata de”: el material, "está inscrita en”: está escrita en la matriz de cada código y como es una matriz, esta permite permutaciones. "Es importante para": el asunto (matter) del mensaje. (...) Finalmente tenemos material, lo cual es cuestión de recepción en el sentido (...) podemos lidiar con este objeto o el objeto que ahora propone una pregunta particular: “ ¿Qué es la maternidad del mensaje hoy?”. Sin importar qué campo estuviese siendo considerado; cocina, pintura o astrofísica”(Ibid pie de página 25)

33 “(...) aglomerados complejos de pequeños paquetes de energía, o de partículas que no pueden posiblemente ser captadas como tal (...) no hay tal cosa como la materia (...) ya no tenemos nada parecido a los materiales, en el antiguo sentido de la palabra, que hablaba de un objeto que ofrecía resistencia a cualquier tipo de acción que intentase de alejarlo de sus finalidades primarias"( Ibid pie de página 25) 
incertidumbre; relevante para nuestra reflexión es la búsqueda de la incertidumbre sobre la "la identidad del individuo humano en su condición de improbablemente inmaterial" (ibid pie de página 25)

Independientemente de la museografía y muy coherente con la epistemología posmoderna, esta no-exposición es un ejercicio metacognitivo acerca de sí misma, y del problema de la exhibición o visibilización de esta y de todas las muestras del arte en la posmodernidad, donde la "exhibición" se puede convertir también en un proyecto artístico en sí mismo. De esta manera, nos lleva al asunto del límite/finitud del arte, tal como lo realizamos y lo concebimos en la modernidad. Se rebasan los límites de arte-tecnología, creador-público, proyecto-obra, materiales-inmateriales, para que la experiencia de aquel laboratorio poroso, nos cuente que hay que reaprender el conocimiento del arte. Hay un nuevo comienzo ya que con Les Inmateriaux se ha llegado a la superación positiva de la finitud. En la imagen, se observa un trabajo con los vestigios, ideas y reflexiones puestas en palabras, cuadros e imágenes, que aluden a la experiencia de fumar tabaco. Y el mediador de aquello que no tocamos pero que entrega el mensaje: el lenguaje escrito y gráfico.

De manera dialogante con lo expresado en la entrevista por su maestro Lyotard, J.L. Déotte reflexiona sobre el vaivén posmoderno entre el intra y el extra museo, cuya oposición nos hace sentido en la actualidad (esto será especialmente pertinente en el proyecto Esto no es un Museo. Artefactos móviles al acecho) y los avatares de los campos conceptuales que estallan en el nuevo escenario. Para las instituciones museales se suma a esto, problemas ligados a la conservación de estas "piezas" (resistencia a su natural degradación y fin), abriendo al museo a una perspectiva ilimitada de crecimiento, y desde un discurso de ficción "el arquitecto debe prever la instalación de colecciones ilimitadas" (Déotte, Catástrofe y Olvido 130). Déotte sitúa estos fenómenos entre

el paso a la abstracción -a comienzos del siglo XX- y la interdicción adorniana de la representación. Situaremos algunos momentos esenciales y trataremos de ubicar los remezones que afectaron la institución de las Luces donde, poco a poco, va a imponerse una luz "nocturna". Las cosas que serán puestas en juego conciernen además de a la luz (...) al tiempo del momento presente (...); el material (y los inmateriales) y ya no la materia(Déotte, Catástrofe y Olvido, 131 el énfasis es nuestro).

Gravita el problema de la definición o antidefinición consecuente por lo posmoderno que se encuentra al centro de Les Inmateriaux. ¿El goce por la finitud...lo inmaterial como imposibilidad, o la imposibilidad como invitación? En una frase que resuena a T. Adorno y las características interdictas del arte hermético, sordomudo o enclaustrado en sus significados (al ser un jeroglífico cuyos códigos de interpretación se han perdido), Lyotard instala una clave que tampoco es certeza: "toda la exhibición podría ser pensada como un signo que hace referencia a un significado perdido. Y este significado (...) es asunto del disgusto que ronda el fin de la era moderna de igual 
forma que el sentimiento de jubilación está conectado con la aparición de algo nuevo" (Ibid pie de página 25). Muerte y nacimiento; catástrofe de la materia-significado modernos... bienvenida el nuevo significado errante de la inmaterialidad. El continuo movimiento de la posmodernidad ya presentido en Benjamin: la crisis es sólo interrupción provechosa del continuo... devenir.

Es así como Les Inmateriaux anuncia un cambio de época tras el fin de los antiguos códigos materiales de comunicación, y es imposible negar el advenimiento de una etapa desconocida e inaudita, ramificándose en nuevas parejas de opuestos; entre ellas y relevante al problema: "la materia se opone a la forma, pero se diferencia en material -en materia/forma-, la de lo suspendido, y en inmateriales" (Déotte, Catástrofe y Olvido 131).

Tenemos en la mano una vez más el Catálogo de Epreuves d'ecriture de la muestra, y una red de conceptos aparecen, susurrando aún, sobre proyectos que no vivimos. Ellos son mensajes, cifrados aún, sobre corps, dématérialisation, écriture, geste, habiter, image, immortalité, improbable, interaction, interface, langage, lumière/ temps, mémoire, métamorphose, signe, vitesse, miroir/matrice, miroir/mutation... La materia del mensaje del mensaje se vuelve intangible o más bien, se concentra en la inmaterialidad del transe comunicativo. Y de esta manera, la inmaterialidad del curso de comunicación pone en evidencia los canales de información y las redes de comunicación inmateriales y "al mismo tiempo, abandona y deja eriazos sitios considerables: bienes (de culto), territorios, idiomas, etnias, Estados-nación” (Déotte, Catástrofe y Olvido 137).

Siguiendo los casos de estudio, proponemos como bisagra entre lo inmaterial de la curatoría de Lyotard y la de Peran, la idea de la "movilización total", que Déotte desarrolla a propósito del museo como modernidad diferida: "esta (la emancipación moderna) se cambia en movilización total que redefine constantemente sus límites (lo inmovilizable) y genera su sombra caricatural (su desestimiento) (...) ¿En qué se convierte el museo cuando la movilización se convierte en la característica de la nueva época? (Déotte, Catástrofe y Olvido 137, el énfasis es nuestro) En un museo "en tránsito" de signos y lenguajes, de vidas y memorias, de interacciones, de gestos vitales.

Les Inmateriaux y Esto no es un museo... se encuentran.

\section{b) El caso de Esto no es un Museo. Artefactos móviles al acecho (2010-2014)}

Esto no es un museo. Artefactos móviles al acecho es un proyecto viajero. Su viaje se inicia en España (Cataluña) y luego se va en itinerancia a Eslovenia (Liubliana), Estados Unidos (Washington), México (Ciudad de México D.F.), Estados Unidos (Lynchburg), España (Barcelona), Chile (Santiago), Estados Unidos (Miami). Se trata de una particular exposición-archivo "en tránsito" comisariada por Martí 
Peran $^{34}$,y producida por ACVIC Centre d’Arts Contemporànices (Centro de las Artes Contemporáneas de VIC, Barcelona, España) en colaboración con AC/E Acción Cultural Española y el CCEMx. Se concibe como un proceso de trabajo que combina investigación y formación, y se exhibe como catálogo y archivo in progress que añade nuevos aportes (del país donde se instala-mueve y de otros invitados), reformulando la idea tradicional del museo como dispositivo de exposición y cautela. Este trabajo de muestra-archivo "en tránsito", se puede definir como un ejercicio de documentación y reflexión sobre la construcción de artefactos móviles, en tanto elementos para una concepción expandida del museo, o en algunos casos, como una alternativa al mismo. Sin duda el fin del museo moderno y el inicio de un museo nómade en un vaivén dentro-fuera, fuera-dentro.

Pero este proyecto no sólo se pone "en marcha" entre continentes, en barrios de grandes ciudades, sino también "navega" por distintos ámbitos de divulgación y discusión. Entre ellos, y parte de las tramas urdidas por el mismo Peran, está la revista Roulotte $^{35}$, la cual posee como línea editorial ser "una especie de exposición móvil en circulación permanente" (Vol. 1, Núm. 1, 2013). También promueven su movilidad en diversos espacios museales y universidades, a través de sus distintos soportes en la redes de divulgación web y también a través de conferencias, seminarios y coloquios ${ }^{36}$. Cada país asumió su propia manera de ponerlo en movimiento, incluso individuos y entidades "no oficiales" hacen lo propio de manera más o menos exhaustiva a través de Internet, en sitios informales, inestables y dinámicos. Y es tal su fluidez, que el sitio creado por México (sitio muy completo e interactivo), fue descargado y quedó inaccesible: se desmaterializó. Consecuencia que no podríamos soslayar.

Pero no estamos ante una primera vez. La búsqueda de subvertir la lógica del museo a través de la construcción de dispositivos móviles, tiene una larga tradición. Desde que Marcel Duchamp presentara su obra Boîte-en-valise (1941), muchos artistas han tratado de llevar la experiencia estética más allá de los límites del museo; superar la mise en vue o expositio, que fuera uno de los desafíos para Lyotard en Les Inmateriaux).

34 Profesor de Teoría del Arte en la Universidad de Barcelona. Crítico y curador de exposiciones, ha participado en diferentes catálogos y libros de arte contemporáneo. Co-editor de Roulotte, colabora en diarios y revistas especializadas (Exit Express, Artforum International). Director del programa internacional Roundabout.Encounter Program entre Barcelona y otras ciudades del mundo (México, Reikiavik, Bangkok, Jerusalén, Santiago de Chile, Estambul). Entre los proyectos más recientes ha presentado Post-it City. Occasional Cities (CCCB, Barcelona, 2008; MAC Santiago de Chile, Centro Cultural São Paulo, 2009); After Architecture (Arts Santa Mònica. Barcelona, 2009).

35 Roulotte (voz fr.) f. Caravana. Pequeña vivienda que se engancha como remolque a un vehículo. Editores: Xavier Arenós · Domènec · Martí Peran/ Roulotte es una publicación editada por ACM/ Con el apoyo de Generalitat de Catalunya, Departamento de Cultura y del Ayuntamiento de Mataró, Institut Municipal d’Acció Cultural. Editorial Revista 01: "Hoy ya no resulta eficaz diferenciar los lugares donde desarrollar la formación, la producción, la exhibición y la documentación. Todas estas posibilidades ya no son episodios aislados en la secuencia de la cultura con-temporánea sino que, al contrario, se solapan en una compleja y única situación donde lo que prevalece es la circulación de datos y el encuentro entre agentes y materiales. Roulotte es un espacio creado para desarrollar este tipo de ejercicio"

36 En Chile por ejemplo Martín Perán y su proyecto fue invitado tanto por el MAC de la Universidad de Chile y por la Escuela de Arte de la Universidad Diego Portales y se sumaron al archivo nómade, iniciativas artísticas de creadores nacionales, cuya propuesta era acorde con la convocatoria de Esto no es un museo. 
En los últimos años, los museos han utilizado dispositivos destinados a hacer arte "portátil" como parte de la absorción de cierta crítica institucional. Entonces, todos los "dispositivos" de Esto no es un museo permiten hacer exposiciones nómadas que funcionan como una "plataforma nómada" como se la ha llamado, para la participación directa y autogestionada del público, en pos del desarrollo de la investigación social y para la articulación de experiencias educativas. Esto ha relevado la simple ampliación de los metros lineales de las paredes del museo, y así, no sólo rompiendo sus límites interiores a un exterior físicamente hablando, sino también proyectándose en un programa de actividades paralelas, que incluyen activaciones de artefactos, talleres y seminarios, distribuidas entre las distintas sedes participantes ${ }^{37}$.

Según el mismo Martí Peran, el cuestionamiento del museo tradicional está siendo acechado por una gran cantidad de proyectos e iniciativas alternativas y aparatos paramuseísticos, los cuales estarían acelerando por una parte la apertura a una nueva sensibilidad y participación lejos de la hegemonía burguesa, y por otra, exigiría el replanteamiento de roles y funciones para un supuesto público homogéneo en las añejas instituciones museales ${ }^{38} \cdot$ ¿Por qué? pues los dispositivos móviles denominados por el curador como "artefactos" son obras de arte que se mueven por la ciudad en busca del contacto con la realidad urbana, con sus habitantes, con lo cotidiano; nada más lejos del encierro en un coto museal.

El curador distingue al menos cinco diversos perfiles y funciones que los artefactos ponen en juego:

a. Los que operan como contenedores móviles y multifuncionales para albergar la potencia de una creatividad nómada y sus respuestas a las necesidades locales.

b. Los artefactos que se conciben como espacios relacionales y de intercambio de bienes, de saberes o de habilidades.

c. Los que priorizan un rol formativo, convirtiendo el artefacto en un dispositivo educativo y de servicios.

d. En otra categoría el aparato móvil se convierte específicamente en una herramienta de investigación.

37 En otras palabras, Marti Peran dice que "si los pabellones temporales del museo convencional pretenden ampliar sus tiempos y espacios de aparición con el objeto de fortalecer la propagación de sus modelos narrativos, los artefactos móviles que acechan al museo serán aquellos que, transitando por el mismo paisaje social, ensayan maneras de entender la célula expositiva como un lugar de recepción y construcción de las narrativas plurales y críticas frente al modelo hegemónico"(http://acvic.org/es/in-situcast/300-ceci-naest-pas-une-voiture-artefactosmoviles-acechan-al-museo, capturado en Marzo del 2014/ también en http://www.idensitat.net/es/idceci-nestpas-une-voiture-sp-1618648289/737-espacios-transitos-y-dispositivos-moviles, ambos sitios catalanes)

38 "En el archivo Esto no es un museo. Artefactos móviles al acecho (...) se da cuenta de más de medio centenar de proyectos e iniciativas ideadas como instrumentos alternativos a la institución artística convencional (...) Parece que el museo tradicional, en efecto, padece una suerte de creciente acecho desde un enorme panel de réplicas que, mediante las actuaciones que propician, estarían acelerando la refundación de los roles y funciones tradicionales que ejercía la vieja institución en el interior de una esfera pública homogénea. (...)Los nuevos artefactos paramuseísticos despliegan un abanico de situaciones heterogéneas" (Martí Perán citado en http://www.revistapuntodefuga.com/?p=971. Del Cuadernillo de la muestra en Chile, MAC; By Punto de Fuga 28 enero, 2014 Arte Contemporáneo, Artistas chilenos, Institucionalidad artística, Mariairis Flores) 
e. También hay artefactos que aspiran, de forma prioritaria, a vehicular voces de disidencia social y política. En la imagen siguiente, vemos uno de los proyectos en Chile (mostrado en el MAC de Quinta Normal), que muestra el camino de un flâneur por las galerías comerciales del centro de Santiago y su relación con nuestra sociedad de consumo y fascinación por lo foráneo.

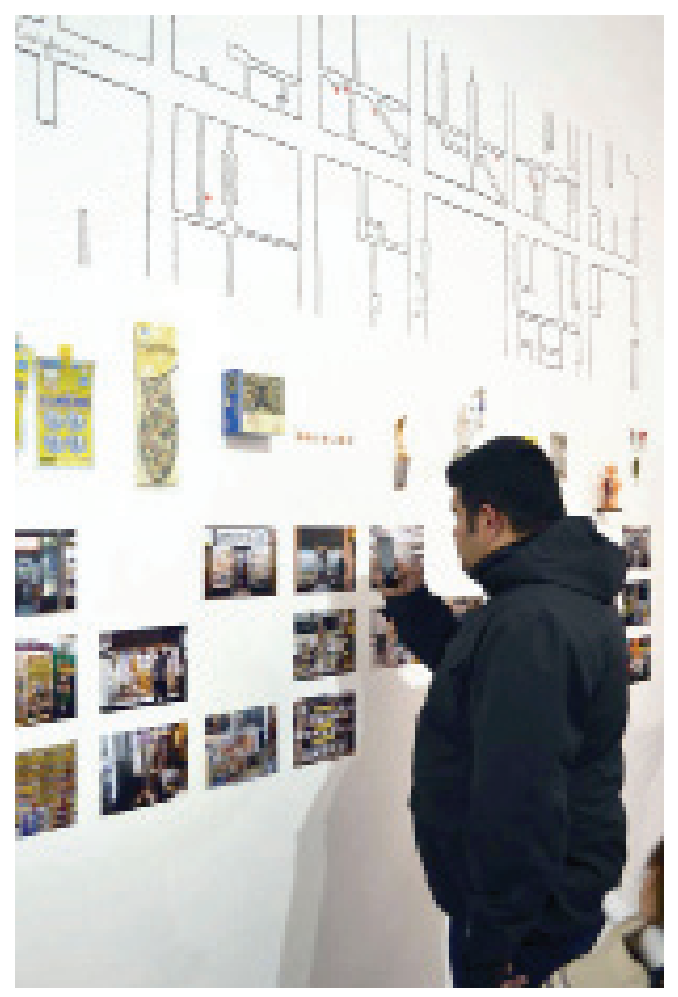

Figura $2^{39}$

Los principios del proyecto son presentados por Peran en un soporte igualmente móvil: una revista ${ }^{40}$. No existe catálogo oficial de las muestras. El sesgo de los principios, es estético-político-museológico, y arma una trama provocadora, que nos permite adelantar la certeza que nos encontramos ante este archivo-no archivo de este no museo, un genuino proyecto curatorial de naturaleza transitiva:

39 Fuente: Revista Punto de Fuga, publicado el 28 de enero, 2014 / Arte Contemporáneo, Artistas chilenos, Institucionalidad artística, Mariairis Flores. Artículo: Esto no es un museo: esto es un curatoría ambivalente. Iniciativas chilenas al acecho. Fecha de ingreso 3 de Abril de 2014. <http://www.revistapuntodefuga.com/?p=971>

40 Revista de Estudios Globales y Arte Contemporáneo, Vol. 1, Núm. 1, 2013, 111-119 
[Movilidad] Peran declara una apología de lo móvil y flexible que procede, en primer lugar, de las estructuras hegemónicas, proclives a glosar las supuestas virtudes de un capital deslocalizado y en perpetuo movimiento (...) Los programas políticos, económicos y de fabricación de subjetividad se han traducido (...) en cálculos de movimiento y en gestión de desplazamiento (Revista de Estudios Globales y Arte Contemporáneo 112).

Esta evidencia ha convertido a la movilidad en una cuestión recurrente en el interior de la cultura crítica ${ }^{41}$. Entonces, los artefactos de Esto no es un museo han de inscribirse en esa exploración y despliegue de la movilidad por su capacidad deformadora, mediante la cual se transgreden las convenciones proyectadas sobre el territorio físico y social de la ciudad. Aquí la ciudad (que luego llamaremos porosa) cumplirá un papel fundamental en la circulación disruptiva de los artefactos rodantes ${ }^{42}$. Estos promueven "anomalías estéticas, pedagógicas y políticas que rompen con la lógica y el consenso de la representación". Nos encontramos con una propuesta de disenso estético al modo rancieriano ${ }^{43}$, donde los llamados "museos portátiles" funcionan como "dispositivos de escucha y de acción para que la heterogeneidad de la esfera pública canalice sus imaginarios, autogestione su representación, formalice sus emergencias y articule sus propias soluciones" (Revista de Estudios Globales y Arte Contemporáneo 113), convirtiéndose en un ejercicio político significativo a un colectivo que participa; qué lejos está de aquel museo todavía anclado en la liturgia de la contemplación.

Cada museo portátil se piensa como un microsistema organizado, que como una alternativa al museo tradicional, no siempre aspira a desarrollar un antagonismo radical que persiga desplazar y substituir lo museal instituido; esto es coherente con la propia idea de movilidad y flexibilidad que estos artefactos ponen en juego:

a. En primer lugar hay artefactos ideados para una movilidad circular, caracterizada por proceder desde un centro de origen hacía distintos puntos de destino para regresar al punto de partida. En esta modalidad, los museos portátiles, promovidos desde el propio contexto institucional, se convierten en herramientas con las que el mismo sistema artístico intenta redefinir sus funciones en pro de un reencuentro con los mundos sociales y culturales reales.

b. Una segunda modalidad es la movilidad descentrada que acontece cuando los

41 Entre los numerosos proyectos que podrían mencionarse en esta perspectiva, véanse: Geography and the Politics of Mobility. Generali Foundation. Viena, 2003; Ambulantes. Cultura portátil. CAAC. Sevilla, 2004; Mira como se mueven. 4 ideas sobre movilidad. Fundación Telefónica. Madrid, 2005.

42 "Allá dónde el urbanismo pretende codificar los comportamientos y ordenar la distribución del capital y de las mercancías, la irrupción de artefactos rodantes inyecta sobre ese mismo territorio situaciones y prácticas inesperadas que fracturan la estructura regular del espacio social"( Revista de Estudios Globales y Arte Contemporáneo, Vol. 1, Núm. 1, 2013, pag.113)

43 Como platea Rancière (El tiempo de la igualdad 21), el disenso vinculado a una emancipación estética, se entendería como una ruptura del equipamiento intelectual y sensorial en la construcción de un tejido disensual. 
trayectos multiplican sus direcciones; el resultado es una circulación en la que los artefactos se desplazan de forma irregular hasta el siguiente emplazamiento. Esta movilidad más rizomática responde a la naturaleza autogestionada del aparato, liberado de cualquier estructura institucional y de toda ruta preestablecida ${ }^{44}$.

c. Lo que podríamos denominar movilidad detenida se refiere a las experiencias de museos portátiles que acumulan distintos emplazamientos. Se trata, de iniciativas nómadas que ahora se desarrollan en un lugar determinado y otrora en un lugar distinto.

[Crítica institucional] En tensión con el problema del cuestionamiento y catástrofe del museo y lo museal institucional bajo la mirada del control político, Peran instala este principio, y declara ante el desmoronamiento general de la esfera institucional, que no es más que una de las múltiples consecuencias de la crisis de la representación ${ }^{45}$. Para el curador, solo en la medida que los museos portátiles intervienen y se distinguen del sistema convencional del arte, pueden desarrollar una crítica efectiva capaz de actualizar el potencial de la experiencia estética y, al mismo tiempo, instalar al museo en una situación de refundación permanente acorde con esa potencialidad ${ }^{46}$.

Pero hay que considerar que la institución artística, aun permaneciendo bajo sospecha, siempre tendió a una actitud reformista y autocrítica ${ }^{47}$; desde el replanteamiento del dispositivo “exposición”, la nueva construcción de públicos participativos, hasta la panacea de las fábricas creativas.

El curador recuerda que desde que Robert Smithson en 1972 advirtiera sobre los peligros del confinamiento cultural $^{48}$, la obsesión del sistema artístico por reencontrarse con la exterioridad ha sido constante. La clave para Peran es lograr el engarce entre el interior y el exterior asegurando así la disolución de esa tensión, y más aun,

44 Con esta radical modalidad de movilidad, los museos portátiles como el Museo Ambulante (32) o el Centro Portátil de Arte Contemporáneo (05) se articulan como verdaderas microestructuras alternativas al museo convencional y operan como otras plataformas para la construcción de una subjetividad plural que apenas puede ser gobernada por sus mismos promotores.

45 Para Peran en este contexto "la esfera institucional consolidada, desde el ámbito político al ámbito estético, padece un descrédito de muy difícil reparación y frente al cual deviene imprescindible ensayar nuevas prácticas instituyentes" (Revista de Estudios Globales y Arte Contemporáneo, Vol. 1, Núm. 1, 2013, pag.115)

46 Dice Peran que "los artefactos móviles tan pronto pueden operar como elementos de fisura interna que deberían mejorar y así reforzar al propio sistema como, por el contrario, se resuelven desde una voluntad de independencia radical y emancipatoria respecto de las consignas derivadas del Museo. Esta ambivalencia, sin embargo, lejos de convertirse en el pretexto argumental para neutralizar su eficacia, es precisamente lo que permite evaluar el perfil de estos artefactos en calidad de herramientas para una crítica institucional" (Revista de Estudios Globales y Arte Contemporáneo, Vol. 1, Núm. 1, 2013, pag.116)

47 Los esfuerzos por reconocer el grado de desmoronamiento del Museo para paliar sus consecuencias o, incluso, para reconstruirlo sobre sus ruinas, son incontables. En nuestro contexto específico, valgan, por ejemplo, la insulsa introspección desarrollada en 10.000 francos de recompensa (El Museo de Arte Contemporáneo vivo o muerto) (Adace, Unia, Seacex. Madrid, 2009) ó el más académico trabajo de El Medio es el Museo (Fundación MARCO. Vigo, 2008)

48 Robert Smithson. “Cultural Confinement”. En Jack Flam (ed) Robert Smithson: The Collected Writtings. University of California Press. Berkeley-Los Angeles- London, 1996. pp. 154-156 
garantizar que las propias prácticas artísticas desarrollen una autocrítica sobre sus condiciones de posibilidad y sus condiciones de producción (donde), no hay un afuera desde el Museo, sino una exterioridad ajena al marco institucional, por donde fluyen los mundos de vida y donde las posibilidades y necesidades de una esfera pública plural podrían aliarse con el arte para instituirse en calidad de nuevos agentes sociales (Revista de Estudios Globales y Arte Contemporáneo 117).

Esta es la utopía de los museos portátiles que operan como un desbordamiento de lo artístico hasta convertirse, en una actividad del tipo pedagógico o de producción de servicios heterogéneos de un colectivo participante, siendo una herramienta crítica.

La capacidad de los artefactos portátiles de producir un espacio social (de encuentro), reside precisamente en su naturaleza disruptiva, entrometiéndose en las lógicas de la planificación espacial ordinaria ${ }^{49}$; pero ello es factible en la medida que los artefactos son objetos reales que, así como reivindican las calles como arterias del espacio público, también pueden ocupar y obstaculizar esas vías para generar un emplazamiento ocasional. Estos artefactos-objetos-museos-espacios nómades en su materialidad, actúan como "un liviano sistema de posibilidades que, en su despliegue, apuntan siempre más allá del arte. Al fin y cabo, esto no es un museo" (Revista de Estudios Globales y Arte Contemporáneo 117, el énfasis es nuestro).

Si planteamos que en la época de la globalización, los grandes protagonistas son los curadores, podemos afirmar que J.F. Lyotard con Les Inmateriaux y Martí Peran con Esto no es un museo. Artefactos móviles al acecho han sido buenos ejemplos de ello. A partir de la reedición de la obra de arte, abren nuevos campos de reflexión y nuevos capítulos de la historia de la autonomía del arte, de la filosofía del arte y de la estética contemporánea. En este marco es posible entender lo transitivo de los espacios del arte como su desborde. Esto sería producto de la crisis o la catástrofe de la vida cotidiana (o para otros su material, su significante mismo) en tanto "existencias cotidianas en emergencia”, cuyo canal de expresión sería el arte, pero lejos -muy lejos- de las academias y de las instituciones tradicionales que lo validan y lo cautelan política y estéticamente.

\section{Arte y espacios nómades. Catástrofe y finitud como posibilidad}

El pensador austriaco Alois Riegl (1858-1905) en El culto moderno de los monumentos: caracteres y origen (1987) dice que es necesario considerar que cuando la creación del ser humano toma forma, ya comienza a experimentar la actividad destructora de la naturaleza: la finitud de un monumento, se instala desde su inicio. Pero ¿qué

49 Naturalmente lo planteamos desde los conocidos postulados de Henri Lefebvre (La production de lespace. Anthropos. Paris, 1974) 
rendimiento filosófico podría tener por una parte el constatar dicha finitud, y por otra, el afán conservador de los espacios del arte, esmerándose por resistirle?

Si se busca preservar aquella ruina o monumento, es porque la antigüedad (remota, cercana o inmediata) posee valor para un grupo humano (sociedad o cultura). En este caso ¿aún le damos un valor a las obras de arte por lo cual "merecen” ser cauteladas? Déotte plantea que cada época define su vínculo estético con el arte, tras una ley determinada. Esto incide en nuestra relación con su aparecer y su desaparecer, con la cautela de su existencia o con la testificación de su ruina ${ }^{50}$.

Considerando a Hannah Arendt (1906-1975) en la Condición Humana (2011), el hombre del siglo XX espera que las obras degraden naturalmente, ya que toda creación humana es concebida como un organismo natural y como tal, el hombre no debe sino cuidarla de un fin prematuro. Y no nos estamos refiriendo a su restauración material, sino a la conservación de lo que busca expresar, comunicar y reflejar. Para Déotte, siguiendo una vez más a Blanchot, es justamente este naturalismo aplicado a la estética en el siglo XX, el que puede fundamentar un vaivén en las obras de los museos. Aquí ocurre por una parte, un movimiento de resistencia al fin anticipado de esas obras -convirtiéndose "en el sitio propio de las obras" y por otra, un movimiento de fragmentación de su contenido en tanto "disolución material (formal)".

Las obras se comunican silenciosamente, en un "verdadero rumor museal" dice Déotte, relacionándose y tocándose en una red imaginaria, cuidadosamente tejida por un curador o un coleccionista -como ocurre en el Museo de Malraux o en el Atlas Mnemosyne de Aby Warburg ${ }^{51}$. Pero este rumor puede ser un "diálogo de sordos" si el espectador no está atento a lo que "se habla": el contenido, problema, lenguaje, la "configuración interna de esta materia" (Déotte, Catástrofe y Olvido 46,) que sustenta el valor estético de la obra y justifica su inclusión en una colección. Y desde una materialidad o inmaterialidad, las obras escuchan y son escuchadas: curvas quebradas del mármol, madera con caracteres geométricos, la textura pintada de una piel, las tensiones de una estructura arquitectónica junto al silencio en el vacío de una pantalla... Relaciones nuevas, siempre nuevas, donde la clave es el flujo comunicativo de voces (como en Les Inmateriaux y el rumor de los discursos del público). De esta manera, se arruina el principio de identidad, erigiéndose una red de vínculos de identidades, voces inestables y vagabundas ${ }^{52}$.

50 Déotte especifica que "la ley estética fundamental de la época puede ser formulada como sigue: exigimos de la mano del ser humano que produzca obras terminadas y cerradas, símbolos de la ley de creación. Es evidente que ya no compartimos los mismos valores en cuanto a la creación y en cuanto a la ruina, puesto que nuestro arte está, de partida en ruina" (Déotte, Catástrofe y Olvido 45).

51 Acciones como el Atlas Mnemosyne de Abby Warburg dan cuenta de la importancia de la organización y composición de un grupo de obras dentro de una colección. Las imágenes, carentes de texto resultan atemporales y por lo tanto, de múltiple interpretación. La colección tiene el poder de reorganizar la historia.

52 Sobre la comunicación en los museos Déotte dice que: "un efecto extremadamente importante de este doble proceso -el Museo- es que las obras van a comunicarse entre ellas, de una manera totalmente imprevisible e imaginaria. Es el principio de identidad -sin el cual no hay historia de arte ni historiografía general- el que aparece al mismo tiempo arruinado" (Déotte, Catástrofe y Olvido 47) 
Por una parte, la visionaria propuesta de Warburg, reafirma las ideas de transitividad y porosidad, pues exhibe un mapa que asocia y resignifica la transmisión cultural de las imágenes, por medio de relaciones perceptuales y visuales que traspasan las fronteras de la tradición escrita. La ausencia de texto nos conecta con un conocimiento visual diferente, proponiendo un nuevo orden transcultural en la decodificación e interpretación de dichas imágenes.

Por otra parte, un museo imaginario se deshace peligrosamente en la inmaterialidad; pero no podemos negar la ganancia de esa catástrofe ad portas (bajo la lógica de la modernidad), pues desde su ausencia de paredes, de marcos, de cuadros y de esculturas, este logra un gran provecho: crea tramas y relaciones entre obras disímiles que entran y salen, en una oscilación orgánica, en una vitalidad dialogante, donde el sujeto que "ingresa" en su imaginario, puede caminar en plena libertad. Se instalan así los museos sin creaciones materiales como el museo de Malraux y Les Inmateriaux de Lyotard, donde las obras interactúan usando un lenguaje "disuelto" en una presencia desde la ausencia.

Si las obras se encuentran tras el vaivén rancieriano del dentro-fuera, surge la necesidad de poner a prueba la relacionalidad espaciotemporal del arte. Proponemos seguir la ruta de Bourriaud con la idea de una estética relacional. Esta se inscribe en el "materialismo del encuentro o materialismo aleatorio" planteado por Althusser, donde la contingencia del mundo no tiene origen, ni sentido que le precede, ni razón que le asigne un propósito ${ }^{53}$. Esto abre el azar como mecanismo.

La posibilidad de un arte relacional, está basado teóricamente en la esfera de las interacciones humanas y su contexto social (anticipamos el rol que cumplirá la ciudad), desechando la idea de un espacio simbólico autónomo y privado, lo cual “da cuenta de un cambio radical de los objetivos estéticos, culturales y políticos puestos en juego por el arte moderno" (Bourriaud Estética Relacional 13). Este arte se comprende bajo la clave del encuentro... como un "lugar de reencuentro", tal como se suscita en los museo-no museos nómades de Peran.

¿Es esta relacionalidad y su multiplicidad de reencuentros, otra señal de la resistencia a un fin del arte y sus espacios museales? En pos de este afán implícito, Bourriaud da un paso más adelante, proponiéndonos una estética que opta abiertamente por lo nómade y lo topológico: surge una estética radicante ${ }^{54}$. Para nosotros

53 En sus últimos escritos de los años ‘80 Althusser busca rescatar lo que llama una "corriente subterránea” del materialismo. Las categorías que dominan ahora el discurso filosófico de Althusser ya no son la de determinación o estructura, sino el vacío y la contingencia. Este "materialismo aleatorio" se basa en una relectura del atomismo de Epicuro según el cual el mundo había surgido de un encuentro fortuito entre átomos, producto de una desviación (clinamen) que había alterado su dirección paralela. Esto demostraría que todo encuentro es aleatorio tanto en sus orígenes, porque pudo no haber ocurrido nunca, como en sus efectos.

54 Dialogando con Deleuze y Guattari de Mil Mesetas, Bourriaud usa el concepto de una familia botánica (los radicantes) para explicar las características de este individuo que luego tendrá una correlación en el arte, su estética y sus espacios: "El sujeto radicante se presenta como una construcción, un montaje" (Nicolás Bourriaud Radicante, 2009 pag. 62). A diferencia del rizoma de Deleuze, lo radicante siempre implica un sujeto, tomando "la forma de una trayectoria, de un recorrido, de una marcha efectuada por un sujeto singular" (Bourriaud, Radicante 61). 
esta idea es pertinente, sobre todo porque lo radicante se entiende como el recorrido de un sujeto singular (enfatizamos la presencia de un sujeto, si bien esto no marca una identidad estable y cerrada en sí misma), que se constituye "bajo la forma dinámica de su errancia" (Bourriaud, Radicante 61). El movimiento de este sujeto es el que le permite la constitución de una identidad; podríamos llamarla una identidad radicante, o identidad en tránsito, y se establece como dialogo intersubjetivo entre el sujeto y las superficies que cruza, generando en su recorrido, una instalación precaria y transitoria. Esto último incidiría en una expresión artística donde el sujeto creador y su proyecto se constituyan como un montaje provisorio e infinito ¿Y este sujeto? Se trata de un ser "atormentado entre la necesidad de un vínculo con su entorno y las fuerzas de desarraigo, entre la globalización y la singularidad, entre la identidad y el aprendizaje del Otro" (Bourriaud, Radicante 57). Por su parte, el arte contemporáneo en tanto "laboratorio de identidades" (Bourriaud, Radicante 57) es el que le da a este sujeto en constante desarraigo, nuevos modelos de expresión, donde entre otros, reutiliza estructuras ya existentes y acepta "ser el inquilino de las formas presentes (...) lo que también puede significar el trazado de una errancia calculada" (Bourriaud, Radicante 63).

De esto último se puede entender la idea bourriaudiana de una obra-trayecto u obra "en tránsito" como preferimos llamarla, un espacio del arte coherentemente "en tránsito" y un creador o espectador como "pasajeros en tránsito". Todo se entiende desde un itinerario que dialoga con un fin potencial...con un fin que es el inicio de un nuevo trayecto de naturaleza intersubjetivo, con una obra que se presenta como un montaje y nace "de una negociación infinita", (Bourriaud, Radicante 63), consigo misma y con otras subjetividades, con otras obras y con otros muchos espaciotiempos.

Es así como en lo radicante y "en tránsito" se agotaría el control exhibitorio de las obras de arte, e ingresaría el factor temporal - ergo el desplazamiento y la obratrayecto se vive en el espaciotiempo de un flujo infinito de experiencias, asociaciones y reflexiones. Se derrumba por una parte la disposición "aristocrática” y controladora de las obras de arte en sus espacios -vinculada al sentimiento de querer conquistar un territorio; y por otra parte, la obra ya no se ofrece a la experiencia "como un espacio por recorrer". Tras el rendimiento de la ruina, la obra contemporánea se presenta "como una duración por experimentar, como una apertura posible hacia un intercambio ilimitado" (Estética Relacional 14), la finitud es una posibilidad para empezar de nuevo, una y otra vez. De una u otra manera, lo expuesto quedó de manifiesto tanto en Les Inmateriaux de Lyotard, como en Esto no es un Museo. Artefactos móviles al acecho De Marti Peran.

Nuevamente se nos aparece un arte fluido y entre comillas, y junto a él, la imposibilidad de instalar un proyecto artístico de naturaleza topológica o de trayecto, en un espacio museal, que en tanto coto de caza protector de sus presas, es cerrado, estable y agobiante. Se precisa un espacio museal ad hoc nómade y poroso: un espacio del arte "en tránsito". ¿Y la ciudad donde sucede? 


\section{Topología y el "arte" trashumante de una ciudad porosa}

En la tríada problemática de porosidad, apertura y transitividad, tanto para Déotte como para Bourriaud es la ciudad contemporánea la que asume un papel protagónico. Ésta dispone y obliga espacios de encuentro entre ciudadanos bajo la experiencia de la proximidad, marcando la trama intersubjetiva como lógica en la creación contemporánea ${ }^{55}$. Esto no es un Museo. Artefactos móviles al acecho, tiene como lugar una ciudad sin cosmética, en la que se visibilizan relaciones entre la gente y sus barrios, intercambios de habilidades y experiencias de diversos ciudadanos, y múltiples y azarosas vinculaciones del arte con necesidades sociales y marcas culturales sin aditamentos; se trata de proyectos "puestos en marcha" en trayectos reales. Podemos hablar de una ciudad trashumante y plena de intersubjetividades.

El arte contemporáneo devendría en el sitio de producción de una sociabilidad específica; en él tanto sus espacios de visibilización como la ciudad que los instala y moviliza, son fundamentales. En las zonas de relación dispuestos por la ciudad, J.L Déotte (En La ciudad porosa, Walter Benjamin y la arquitectura, 2013), destaca dos aparatos urbanos: pasajes y panoramas; que estructurarían según Benjamin, un nuevo tipo de sensibilidad... la del flâneur quien aborda la ciudad habiendo suspendido todos sus conocimientos sobre ella, a fin de hacer posible una experiencia corporal de los lugares, convirtiéndose así en un "explorador corporal de un pasado sin archivos, como el coleccionista” (Déotte 44) ${ }^{56}$.

Será justamente la idea de una ciudad porosa, entendida desde la topología la que, según Déotte, permitirá a Walter Benjamin llevar a cabo una nueva rearticulación de aquello que ha sido precisamente disociado: lo psicosocial. En la ciudad actual lo privado se disocia de lo público, por lo que el acontecimiento ya no da lugar a una experiencia psicosocial; esto es coherente con la mencionada desconfianza y "fluidez" posmoderna, y se aleja de aquel relato moderno que era capaz de inscribir el acontecimiento en una superficie común, en el ámbito de lo privado (recordemos que la ciudad moderna permitía en lo privado el encuentro entre personas). Nos referimos a la ciudad del flâneur, aquella que se vuelve porosa y deviene en un territorio que se constituye gracias a la movilidad de los paseantes, de la masa o la muchedumbre, en aquella topología donde lo público y lo privado serían reversibles ${ }^{57}$

55 "La ciudad permitió y generalizó la experiencia de la proximidad: es el símbolo tangible y el marco histórico del estado de la sociedad ese 'estado del el encuentro que le impone a los hombres', según la expresión de Althusser (...) El régimen de encuentro intensivo, una vez transformado en regla absoluta de civilización, terminó por producir correspondientes prácticas artísticas: es decir, una forma de arte que parte de la intersubjetividad (...) El arte siempre ha sido relacional en distintos grados, o sea, elemento de lo social y fundador del diálogo. Una de estas virtualidades de imagen es su poder de reunión (reliance)" (Bourriaud, Estética Relacional 14)

56 "A partir de Baudelaire podemos preguntarnos si la problemática política del cuerpo y, en consecuencia, de la encarnación (encarnar un pueblo, una nación, una idea, etc.) es todavía legítima. Es lo que Jünger anunciaba a (...) en El trabajador, con la crisis de la democracia, ya no hay más representación posible del cuerpo " (Déotte, La ciudad porosa, Walter Benjamin y la arquitectura 46).

57 Es por ello que Déotte retoma los textos de Benjamin sobre Berlín, puesto que es ahí donde el filósofo alemán intenta 
Desde la imagen del caminante citadino de los pasajes benjaminianos, nos vamos al inmigrante, exiliado, turista y errante urbano como menciona Bourriaud, quienes serían figuras dominantes de la cultura contemporánea.

El artista que hemos ido presintiendo desde lo nómade y lo radicante, inventa nuevos trayectos entre signos, pone las formas en movimiento, e incluso, el mismo es parte de los múltiples desplazamientos; recortando fragmentos de significación "recoge muestras; constituye herbarios de formas" (59) como lo haría un lúcido caminante en el asombro de sus hallazgos... como lo hizo Warburg y Malraux. Se abandona UN fin, para abrirse a la construcción in progress, abandonando a su vez las exclusividades disciplinarias y los egos creadores como en Esto no es un Museo. Artefactos móviles al acecho, donde la comunidad propone, participa, se mueve, hace mover y los individuos anónimos en casas y barrios de una ciudad porosa, son a su vez creadores "en tránsito" para un arte ídem. Y el arte se trasplanta a territorios heterogéneos, en todos los formatos posibles, para creadores y públicos a espacio abierto y en marcha, disueltos en la vida cotidiana. Entonces podemos afirmar como Bourriaud, de la mítica superación del arte, y con esto, la precariedad o el agotamiento de esos espacios del arte que sólo se definen y se sostienen desde su "adentro".

En términos estéticos, lo anterior nos vincularía con una "tipología de la postproducción" ${ }^{58}$.A partir de ello, la pregunta ya no es: "qué es lo nuevo que se puede hacer”, sino más bien:“ ¿qué se puede hacer con?", es decir, ¿cómo producir la singularidad, cómo elaborar el sentido a partir de esa masa caótica de objetos, nombres propios y referencias que constituye nuestro ámbito cotidiano, pues „las cosas y las ideas brotan o crecen por el medio, y es allí donde hay que instalarse, es siempre allí donde se hace un pliegue“ (Deleuze Pourparlm 219, citado por Borriaud en Postproducción: La Cultura Como Escenario. Modos en Que el Arte Reprograma el Mundo Contemporáneo) Al igual que el arte de la post producción, los espacios de visibilización deberán responder a la multiplicación de la oferta cultural, recogiendo entre otras, las formas de saber generadas por la aparición de la red. Es así como el arte y sus espacios buscan orientarse en el caos cultural, deduciendo de este, nuevos modos de generación. Esto es una urgencia para los espacios del arte, que se constituyen ellos mismos como territorios porosos, en un dentro-fuera o un fuera-dentro de las redes culturales.

hacer una topología de su vida a través de la estructuración de la ciudad. Es decir, la ciudad es la que determina su biografía, y lo público y lo privado logran intercambiarse a través de esta topología.

58 Para Nicolás Bourriaud, "post producción" es un término técnico utilizado en el mundo de la televisión, el cine y el video, designando el conjunto de procesos efectuados sobre un material grabado, esto es, un conjunto de actividades ligadas al mundo de los servicios y del reciclaje del sector terciario. Desde comienzos de los años noventa, un número cada vez mayor de artistas interpretan, reproducen, reexponen o utilizan obras realizadas por otros o productos culturales disponibles. (Post producción. La cultura como escenario: modos en que el arte reprograma el mundo contemporáneo, Adriana Hidalgo editora, 2009). 


\section{Recogiendo los pasos. Museología en tránsito y espacios del arte inmateriales y errantes}

Más allá de la crítica que ha acompañado a la modernidad desde que ésta fue formulada entre los siglos XVIII y XIX, las marcas profundas del pensamiento posmodernista apuntaría a la fragmentación, indefinición y descreimiento. Cómo olvidar el énfasis de Foucault en torno a la discontinuidad y la diferencia en la historia, y el privilegio que se le otorga a las correlaciones polimorfas en lugar de la causalidad simple o compleja como diría Jacques Lacan ${ }^{59}$; cómo olvidar los nuevos desarrollos de las matemáticas que destacan la indeterminación (catástrofe y teoría del caos, geometría fractal), la reaparición de la preocupación por la ética, la política y la antropología, por el valor y la dignidad del "otro". Todo indica la necesidad de cambio extendido y profundo en el régimen del arte y con él, en el estatuto de una nueva sensibilidad común tal como lo pensaba Ranciére; en la actualidad se instala una nueva forma de sentir el arte desde los diversos proyectos; en ellos, inicio y fin se encuentran, o dónde el fin de las certezas expresivas y expositivas, el fin de las materialidades y de las rutas convergentes, ya no son el único periplo en pos de una experiencia estética ${ }^{60}$.

Visionariamente, Rancière ha afirmado que el museo es un espacio esencial del arte "porque el arte es ante todo, aquello que es objeto de experiencia estética, y esta (la del museo) es una reconfiguración de los espacios-tiempos de una sociedad" (Sobre Políticas Estéticas 69); por eso no se pretende destruir o abolir el museo o lo museal, sino transformarlo constantemente. Porque, si el museo tradicional se entendía en relación a un edificio, una colección y un público, el nuevo museo y los nuevos espacios del arte se comprenden como un territorio, un patrimonio y una comunidad. Esto supone una estructura descentralizada, la existencia de lo material tanto como de lo inmaterial, de lo natural y cultural en constante desarrollo y mutación.

Tanto desde la teoría, como en las acciones curatoriales, JF Lyotard, Nicolás Borriaud, Jaen-Louis Déotte y Martí Peran plantean de una u otra forma que la "condición posmoderna" nos trae consigo no sólo los efectos insoslayables de una sociedad globalizada marcada por la post industrialización, y una vertiginosa aceleración de los modos de vida, sino también abren la bisagra de la placidez cotidiana y de lo artificial, por lo cual se hace necesario un gran giro paradigmático en la museología. Desde aquí es posible entender el surgimiento de una museología crítica con características transitivas y problemáticas, desde su anclaje teórico.

A la luz de lo anterior, la teórica española Francisca Hernández (2006) plantea justamente que la llamada museología crítica, entiende lo museal como un conjunto

59 Aludido en el artículo "Alteridad y Psicoanálisis. El psicoanálisis francés en el fin de siglo, Flora Singer. (1994) Revista uruguaya de psicoanálisis (79-80)

60 Comentario al texto de David Harvey, La condición posmoderna. Investigación sobre los orígenes del cambio cultural, p. 23. 
de ámbitos en un conflicto, donde el patrimonio, la identidad (como espacios artísticos, como culturas errantes) y otros conceptos son puestos en beneficiosa y fructífera discusión. Se deja atrás la idea de estos ámbitos como dispositivos neutros y asépticos, pasando a ser el resultado de discursos y otros mecanismos que están operando en un momento y lugar dado. Sin duda en la posmodernidad nos encontramos en una situación de agotamiento y sospecha de los espacios de cautela del arte, correlativo al "entrecomillado" del arte y su permanente diálogo con la finitud, pero esta es una condición y una posibilidad de desarrollo.

En relación con lo anteriormente declarado, Nicolas Bourriaud ve en la posmodernidad un individuo globalizado que ya no cuenta con un entorno estable que le dispone un territorio para enraizar, y "está destinado al exilio fuera de sí y conminado a inventar la cultura nómada que el mundo contemporáneo exige" (Radicante 87). Por esta razón, este individuo proyecta (o intuye que debe hacerlo, si aún no lo ha efectuado) espacios del arte globales y abiertos a redes insospechadas, a escuchas del nomadismo cultural. Esta idea sería el núcleo de una museología (permítanos decirlo) nómade o en tránsito, extremando la idea de la museología crítica expuesta más arriba. Porque, si el museo tradicional se entendía en relación a un edificio, una colección y un público, el nuevo museo y los nuevos espacios del arte se comprenden como un territorio, un patrimonio y una comunidad. Esto supone una estructura descentralizada, la existencia de lo material tanto como de lo inmaterial, de lo natural y cultural, todo lo cual se encuentran en constante desarrollo y mutación.

Entonces, las resonancias de Lyotard, ante lo concebible y no presentable (visible/materializable) de la posmodernidad, junto a la activa incomodidad frente al anacronismo del museo realizada por Martí Peran, dejarían totalmente inoperantes las políticas estéticas y las operaciones museológicas de la modernidad. En un mundo artístico y no artístico que se bambolea, crea y recrea a partir de referentes, problemas, materiales, medios, visibilidades-invisibilidades, y a escuchas del nomadismo cultural, "el museo" como coto de caza se hace progresivamente poroso y transitivo. Esto incitaría a la museología crítica para que establezca diálogos con la topología, desde la tensión entre el fin del movimiento (detenciones o instalaciones de sujetos, de eventos, de acontecimientos artístico-culturales formales e informales) y el inicio de nuevos desplazamientos en este arte actual entre comillas. Ya hemos visto en los dos casos de la "carpeta de prueba", que en una ciudad trashumante, que se constituye como fenómeno global (y donde el arte es uno más de sus entes vivos), es inconcebible la pervivencia del museo de antaño.

A partir de Les Inmateriaux y Esto no es un museo. Artefactos móviles al acecho, podemos constatar que el fin es sólo parte de un flujo problemático: por una parte, entre un lábil y aún vigente vaivén entre modernidad y posmodernidad, y por otra parte, es parte de una finitud que pasa a ser material de trabajo (invisible y en exquisito acecho) en un tiempo que no rehúye la incertidumbre; el fin también se reconoce familiar a una ruina/catástrofe como posibilidad; ella es resistida pero también cuidada en los 
museos, manifestando la frágil presencia de un pasado artístico, que irrumpe en un presente móvil, y se proyecta hacia futuros ídem.

En los espacios del arte contemporáneo, el fin es un modo de ser, de instalarse, de desintegrarse, para luego resurgir diciendo en acto o en silencio, que es preciso sospechar de los proyectos que se congelan o guardan en un cubo cerrado, sin relación con un mundo social, cultural y político que lo reclama. Y lo exige.

¿Cómo podría existir un fin en estas condiciones?

\section{Referencias}

Arendt, Hanna. La condición humana. Trad. Ramón Gil Novales. Barcelona: Paidós, 2005. Medio impreso.

---. La Crisis de la cultura: Su significado político y social. En Entre pasado y futuro. Ocho ejercicios de reflexión política. Barcelona: Península, 2003. Medio impreso.

Benjamin, Walter. Libro de los Pasajes. Trad. L. Fernández. Ed. Rolf Tiedemann. Barcelona: Akal Ediciones, 2005. Medio impreso

---. Discursos interrumpidos. Madrid: Taurus, 1973. Medio impreso.

Bourriaud, Nicolas. Estética Relacional. Trad. C. Beceyro y S. Delgado. Buenos Aires: Adriana Hidalgo Editora. 2006. Medio impreso

---. Radicante. Trad. M. Guillemont. Buenos Aires: Adriana Hidalgo Editora. 2009. Medio impreso.

---. Post producción. La cultura como escenario: modos en que el arte reprograma el mundo contemporáneo. Buenos Aires: Adriana Hidalgo Editora, 2009. Medio impreso

Deleuze, Gilles y Félix Guattari. Mil mesetas: capitalismo y esquizofrenia. Trad. J. Vázquez Pérez, U. Larraceleta. Valencia: Pre-Textos, 1988. Medio impreso.

Déotte, Jean-Louis. Catástrofe y olvido: las ruinas, Europa, el museo. Trad. J.P. Mellado. Santiago: Cuarto Propio, 1998. Medio impreso.

---. ¿Qué es un aparato estético?: Benjamin, Lyotard, Rancière. Santiago: Metales Pesados, 2012. Medio impreso.

---. La ciudad porosa. Walter Benjamin y la arquitectura. Trad. N. Calderón. Santiago: Metales Pesados, 2012. Medio impreso.

---. La Época De Los Aparatos. Filosofía, Filosofía Moderna y Contemporánea. Trad.

A. Oviedo. Buenos Aires: Adriana Hidalgo Editora, 2013. Medio impreso

Hernández, Francisca. Planteamientos teóricos de la museología. Gijón, Asturias: Trea. 2006. Medio impreso,

Lucrecio. Rerum Natura. Trad. E. Valentí Fiol. Barcelona: Acantilado, 2012. Medio impreso.

Lyotard, Jean François. La condición postmoderna: informe sobre el saber. Trad. M. 
Antolín Rato. Madrid: Cátedra, 1984. Medio impreso.

---. La posmodernidad: explicada a los niños. Trad. E. Lynch. Barcelona: Gedisa, 1987. Medio impreso.

Lyotard, Jean François y B Massumi "Rules and paradoxes and svelte appendix" Trad. Brian Massumi Cultural critique (1986) University of Minnesota Press. Reproducido en JSTOR. Fecha de ingreso: 12 de enero, $2014<$ http://www.jstor.org/ stable/1354362> Sitio web

Rancière, Jacques. Sobre políticas estéticas. Barcelona: Museu d'Art Contemporani, 2005. Medio impreso.

Riegl, Alois. El culto moderno a los monumentos: caracteres y origen. Trad. A. Pérez López. Madrid: Visor, La balsa de la Medusa. 1987. Medio impreso.

Rojas, Sergio. El arte agotado. Santiago: Editorial Sangría. 2012. Medio impreso.

Stoichita, Víctor. Cómo saborear un cuadro. Madrid: Cátedra. 2009. Medio impreso.

Les Inmateriaux. Epreuves d'écriture. Centre Georges Pompidou. Centre de Création Industrielle, 1985. France. Medio impreso

Présentation «Conférence de presse pour l'exposition Les Immatériaux du 28 mars au 15 juillet 1985», du mardi 8 janvier 1985, dans la Grande Galerie du 5e étage du Centre Georges Pompidou Communique de presse. CNAC Georges PONPIDOU. Service des Archives. France. Fecha de ingreso: 17 de febrero $2014<$ http://www.centrepompidou.fr/media/imgcoll/Collection/DOC/M5050/ M5050_A/M5050_ARCV001_CMP-2006072.pdf> Sitio web

Peran, Martí. "Esto no es un museo. Artefactos portátiles y espacio social". Revista de Estudios Globales y Arte Contemporáneo, Vol. 1, Núm. 1, 2013. Fecha de ingreso: 30 de Abril de 2014. <http://revistes.ub.edu/index.php/REGAC/ index $>$ Sitio web.

Peran, Martí. "Esto no es un museo. Artefactos móviles al acecho”. Roulotte: 09. Fecha de ingreso: 30 de Abril de 2014. <http://www.roulottemagazine.com/ es/2012/02/roulotte09/> Sitio web.

Recibido: 23 octubre 2014 Aceptado: 15 noviembre 2014 